\title{
Payments for ecosystem services: a review of definitions, the role of spatial scales, and critique
}

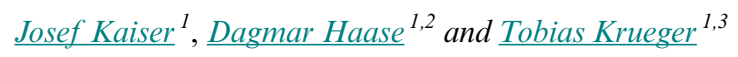

\begin{abstract}
The economic conservation instrument of payments for ecosystem services (PES) enjoys an increasing popularity among scientists, politicians, and civil society organizations alike, while others raise concerns regarding the ecological effectiveness and social justice of this instrument. In this review article, we showcase the variety of existing PES definitions and systematically locate these definitions in the range between Coasean conceptualizations, which describe PES as conditional and voluntary private negotiations between ES providers and ES beneficiaries, and much broader Pigouvian PES understandings that also assign government-funded and involuntary schemes to the PES approach. It turns out that the scale at which PES operate, having so far received very little attention in the literature, as well as critique of PES must be considered in the context of the diversity of definitions to ensure the comparability between studies researching PES programs. Future research should better target linkages between global, regional, and local scales for the development of PES programs, while taking local collective governance systems for a sustainable use of resources into account more seriously.
\end{abstract}

Key Words: collective action; critique of PES; environmental governance; neoliberal conservation; payments for ecosystem services; PES definition; spatial scales

\section{INTRODUCTION}

The critical state of ecosystems worldwide has sparked a debate about which environmental policy instruments are best suited to establish a socially and ecologically sustainable society. In academic as well as political circles the ecosystem services (ES) approach and related policy instruments such as payments for ecosystem services (PES) are highlighted as a promising solution to halt the degradation of ecosystems. The prominent Millennium Ecosystem Assessment defines ES as "benefits that people obtain from ecosystems" (Millennium Ecosystem Assessment 2005:V), although this definition is criticized for its anthropocentric view on ES and its imprecision (Farley and Costanza 2010, GómezBaggethun and Ruiz-Pérez 2011, Danley and Widmark 2016, Farley 2020). Many ES can be denoted as market externalities because of their open access or public good character. From a Neoclassical economics point of view, these services are not properly considered in the decision-making process of economic actors because of their lack of representation within the market sphere (Gómez-Baggethun and Ruiz-Pérez 2011). PES make ES valuable in monetary terms by rewarding ES providers for their conservation efforts using positive and conditional economic incentives, thereby aiming at internalizing market externalities (McElwee et al. 2014). This is why some critics see PES as contributing to the tendency of complementing or replacing classical regulatory conservation policies with economic or even market-based instruments (Sattler et al. 2013). However, in the literature, it is controversially discussed whether PES contribute to an increase of monetization and commodification processes in conservation policies (Gómez-Baggethun et al. 2010, Wunder 2013).

Over the last 15 years, the scientific publications addressing PES skyrocketed. This rise has been paralleled by a growing interest of national governments, as well as of national and international civil society organizations (CSO) focusing on conservation and poverty reduction (Duncan 2006, Huberman 2008, Oxfam 2014). At the same time, the number of implemented PES programs has been increasing. Current estimates assume over 550 PES programs worldwide (Salzman et al. 2018). However, these estimations vary because of the diverging understandings of PES in the literature leading to diverse definitions and conceptualizations (Wunder 2015). Different authors have highlighted already that there is a large range of PES understandings reaching from a narrow Coasean PES conceptualization, where payments from ES users are transferred to ES providers on a private, voluntary, and conditional basis, to the Pigouvian PES conceptualization including also involuntary and governmentally financed programs (Sattler and Matzdorf 2013). Therefore, research projects require a clarification of the underlying conceptualization of PES as a working basis in order to allow for a comparable evaluation of the social and ecological outcomes of PES programs.

It can be assumed that current globalization trends and thus spatial scales affect these ecological and social outcomes of PES programs strongly, since the rapid land use changes and environmental destructions characteristic of our time take place within interconnected, global human-environmental systems (Lambin and Meyfroidt 2011, Meyfroidt et al. 2013). Yet, analyzing the various drivers of environmental destruction and drawing causal relations is challenging because of the very globally telecoupled nature of these systems (Friis et al. 2016). This complexity challenge makes it all the more important to take scale issues into account when designing and evaluating PES programs. And the clear definition basis required to guarantee the comparability between research projects studying PES programs needs to take those scalar dependencies into account.

\footnotetext{
${ }^{1}$ Department of Geography, Humboldt-Universität zu Berlin, ${ }^{2}$ Department of Computational Landscape Ecology, Helmholtz Centre for Environmental Research (UFZ), ${ }^{3}$ Integrative Research Institute on Transformations of Human-Environment Systems (IRI THESys), HumboldtUniversität zu Berlin
} 
Many scholars have a rather skeptical view on PES or even deny the effectiveness of this conservation instrument. For example, some authors criticize that PES potentially downplay the complexity of ecosystems because of the commercialization and commodification tendencies that are often associated with this instrument (Norgaard 2010, Büscher et al. 2012, Scales 2015). Furthermore, the pure focus on monetary exchange values arguably hides the existing plurality of values (Vatn 2010). Other scholars recognize PES as a market-based and neoliberal conservation tool that pushes privatizations and potentially even reinforces existing inequalities (Kosoy and Corbera 2010, McElwee 2012).

We see a need to draw interconnections between these three issues - the diversity of PES definitions, the role of spatial scales for PES program effectiveness, and the existing critique of this environmental policy instrument - to reveal contradictions and research gaps in the current scientific debate. To achieve this aim, our study focuses on the following research questions:

- Which definitions exist for PES and what are the differences between them?

- How is the influence of spatial scales on PES program effectiveness discussed in the literature?

- Which critique of PES schemes is outlined in the literature?

- How does the diversity of definitions affect the research about spatial scale impacts on PES program effectiveness and the accuracy of critique of PES schemes?

To answer these research questions, we applied a systematic literature review. First, we gathered existing PES definitions and classified them according to key features, building on earlier studies by, for example, Wunder (2015). Second, we collected and systemized published research results about the role of spatial scales on PES program effectiveness. Third, we systematically clustered existing points of critique of PES programs using an inductive literature search approach that focused especially on critique of the reputedly neoliberal nature of PES. Fourth, we examined how the existence of different PES understandings affects scale issues and related PES critique.

\section{METHODS}

This review is based on a systematic literature search using the literature database Scopus, because this search engine provides a very high coverage of peer-reviewed literature (Mongeon and Paul-Hus 2016). We developed the underlying search terminologies based on the authors' knowledge and a preliminary analysis of 14 papers that have close thematic associations with the research objectives. After applying the search terminologies in Scopus, we selected relevant papers published between 2000 and 2018 by reviewing the abstracts or, if full-text assessments were required, by reviewing the whole paper focusing on the search terms. This procedure followed the PRISMA guideline (Moher et al. 2009). To aid analysis of the papers found we developed a coding structure using the qualitative research software MAXQDA. The coding structure enabled us to cluster the relevant topics addressing the research questions, which led us to the guiding structure of the results section. When other relevant publications addressing the research questions were referenced within the identified papers, we integrated these publications into the literature review as well (snowball system). Moreover, if statements from other authors relevant to our research interest were cited within the papers, we traced them back to the primary publications. In total, we applied three systematic literature searches referring to the research objectives of this study. A detailed overview of the search terminologies and the papers identified as eligible can be found in Figure 1 and in Appendices $1-3$, indicating also publications that we have detected based on the snowball system.

In the first systematic literature review we identified PES definitions by using two different search terminologies, developed on the basis of five publications that either contain the most famous definitions or give an overview of PES conceptualizations (Wunder 2005, Muradian et al. 2010, Sattler et al. 2013, Sattler and Matzdorf 2013, Wunder 2015). The first terminology includes a full-text search that combines different terms of PES with the word stem "defin*" to include the terms "definition" and "define" as well as further variations. We included both terms "payments for ecosystem services" and "payments for environmental services" as well as the abbreviation "PES" in the search terminology. Although some authors use both terms interchangeably, various differentiations are outlined in the literature (Derissen and Latacz-Lohmann 2013, Souza et al. 2016). For reasons of consistency we only use the term "payments for ecosystem services" in our writing, which is also the most common. However, because we were interested in getting an overview of the full range of definitions, the term "payments for environmental services" was also applied in the literature search. We set the distance between the PES terms and "defin*" at a maximum of 15 words. This number is based on a statement of Elsevier, according to which an average sentence in scientific papers counts 12 to 17 words, leading to a rounded up midpoint of 15 words (Borja 2015). Furthermore, we applied a search within abstracts, titles, and keywords to identify publications containing PES as well as the terms "coase*" and "pigou*," because the nonsystematic pre-literature review indicated the importance of a Coasean and a Pigouvian conceptualization of PES.

Second, we examined the role of spatial scales for PES program effectiveness by searching for the word stem "scal*" in combination with PES in titles, abstracts, and keywords. We did not add limitations such as "geographical" or "spatial" in combination with "scale" in this search terminology, so that no important papers would be missed. Additionally, we used a fulltext search to identify papers containing the combination of PES with the stem of "effectiveness," "efficiency," or "success," again with a maximum distance of 15 words. We grounded the development of this search terminology in publications of Farley et al. (2010), Farley and Costanza (2010), and Ezzine-De-Blas et al. (2016), who highlighted the scale issue in the context of PES programs.

Third, based on the pre-assessment of relevant literature (Robertson 2006, Goméz-Baggethun et al. 2010, Kosoy and Corbera 2010, McAfee and Shapiro 2010, Goméz-Baggethun and Ruiz-Pérez 2011, Muradian et al. 2013), we identified critique of PES applying an inductive approach using the terms "neoliberal*" and "neoclassic*" as entrance gate for gathering publications. We rejected the use of the term "critique" and variations of it, because this search terminology provided too 
Fig. 1. Methodological steps of this study and quantitative results of the literature review.

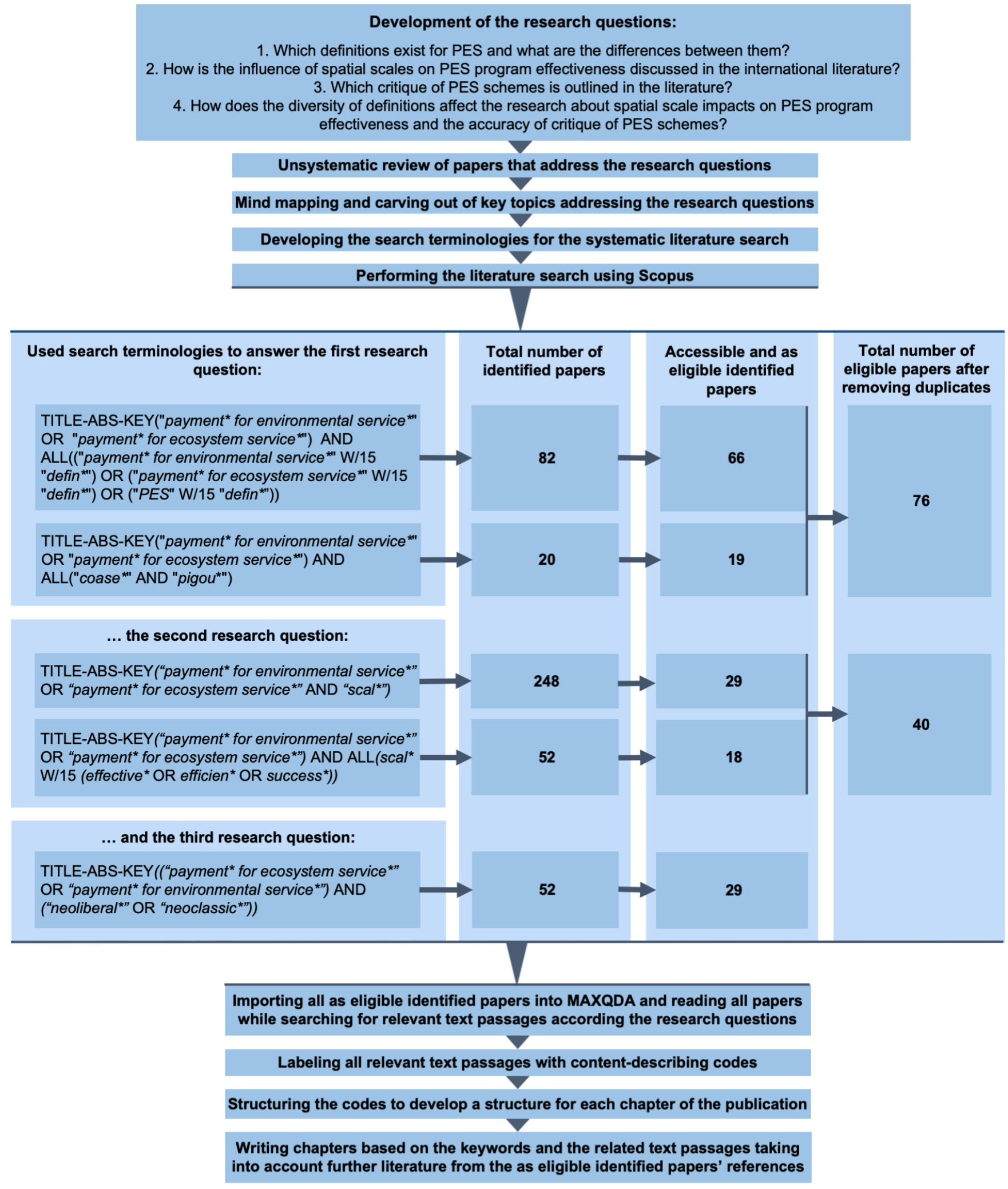


Fig. 2. Number of citations of the publications containing the identified payments for ecosystem services (PES) definitions using Google Scholar; total number of citations between 2005 and 2018 in brackets; highlighting of the two most cited definitions.

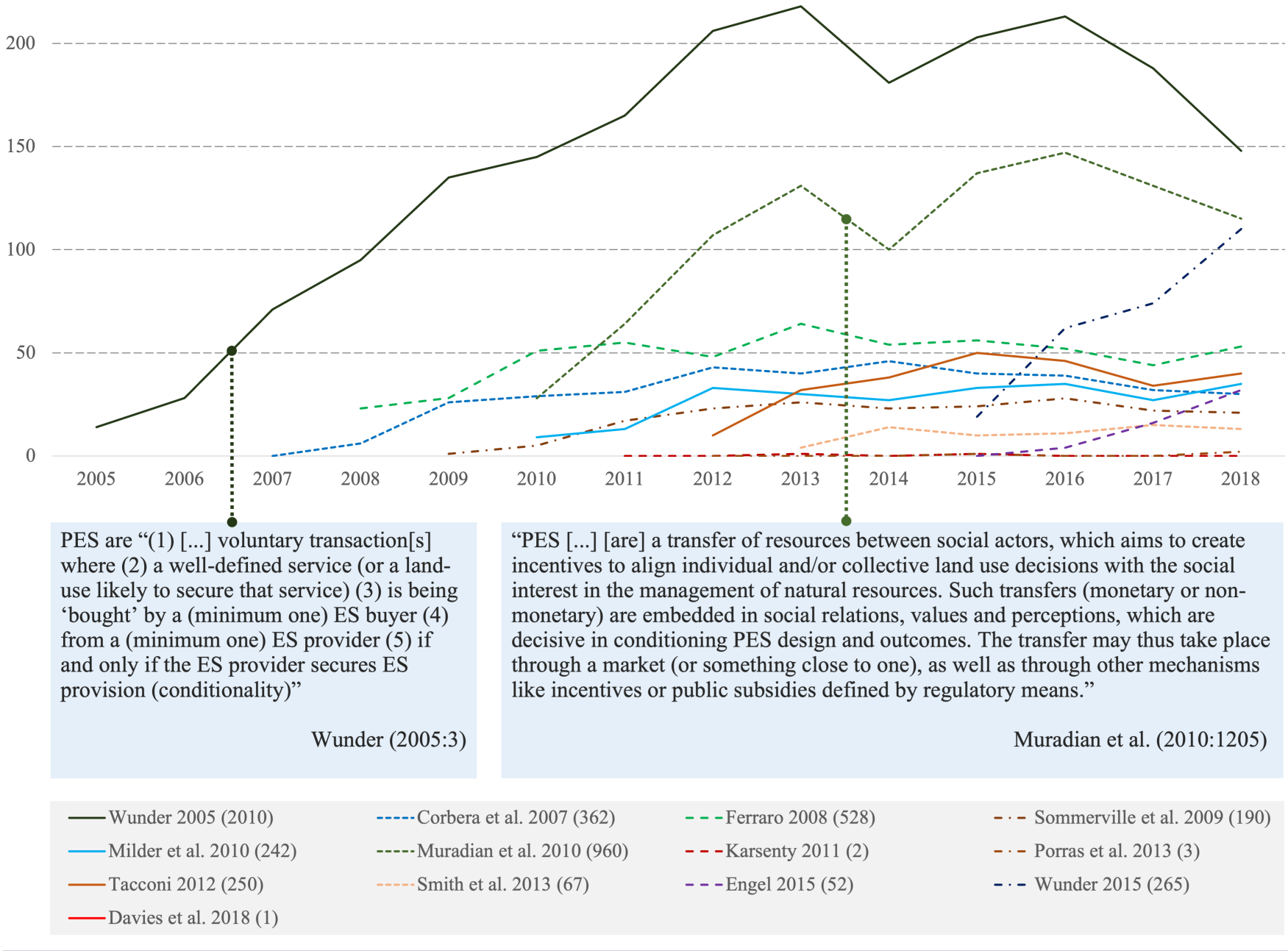

many results not containing critique specifically of PES programs. Thus, we decided to focus on critique that addresses the neoliberal character of PES, which narrowed the results significantly. Nevertheless, this narrow selection was successful in identifying publications touching various highly relevant fields of critique, also by pointing to additional publications.

\section{RESULTS}

\section{PES definitions differ fundamentally}

In total, we identified 76 papers as eligible. Most of them referred to other authors' PES definitions, while only a minority actually came up with new definitions. We detected 13 definitions that aimed at providing a reconceptualization of PES. Some authors also developed new concepts such as "reward-based" definitions. However, such concepts that intentionally transcend the PES debate were excluded to set a focus on the PES term. An overview of alternative terms apart from the classical PES term is given, for example, by Derissen and Latacz-Lohmann (2013).
By far the most cited definition, which is referred to as a Coasean style PES definition, was published by Wunder (2005) and is often mentioned as a market-close conceptualization with reference to the Coase theorem, which highlights the advantages of voluntary private negotiations (Coase 1960). In contrast, a second famous definition by Muradian et al. (2010) is often described as a Pigouvian conceptualization that incorporates (partly) involuntary and not necessarily strictly conditional positive incentive mechanisms. For a detailed description of Coasean and Pigouvian views on PES see, for example, Sattler and Matzdorf (2013). An overview of the citation frequency of the publications containing PES definitions is shown in Figure 2.

Hereafter, the focus is placed on the key criteria we identified by reviewing the 13 definitions. We subdivide the criteria in ex-ante design and ex-post effectiveness criteria. Ex-ante criteria address the concept and design of a specific PES program. In contrast, ex-post criteria relate to the resulting effectiveness and can thus only be evaluated for programs already running. The differing 
Table 1. Overview of criteria assigned to different payments for ecosystem services (PES) definitions.

\begin{tabular}{|c|c|c|c|c|c|c|c|c|}
\hline \multirow{2}{*}{$\begin{array}{l}\text { Author and } \\
\text { year }\end{array}$} & \multicolumn{6}{|c|}{ Ex-ante criteria } & \multicolumn{2}{|c|}{ Ex-post criteria } \\
\hline & Conditionality & Voluntariness & Incentive & Transparency & Directness of transfer & Well-definition of ES & Additionality & Welfare gains \\
\hline $\begin{array}{l}\text { Wunder } \\
(2005: 3)\end{array}$ & required & $\begin{array}{l}\text { buyer and } \\
\text { providers }\end{array}$ & & & buyer to provider & well-defined services & & \\
\hline $\begin{array}{l}\text { Corbera } \\
\text { et al. } \\
(2007: 366)\end{array}$ & $\begin{array}{l}\text { conditionality } \\
\text { is implicitly } \\
\text { mentioned }\end{array}$ & & & & $\begin{array}{l}\text { consumers to provider, but } \\
\text { governments often act as } \\
\text { intermediary }\end{array}$ & ill-defined & & \\
\hline $\begin{array}{l}\text { Ferraro } \\
(2008: 810)\end{array}$ & required & $\begin{array}{l}\text { conservation } \\
\text { agents and } \\
\text { landowners }\end{array}$ & & & $\begin{array}{l}\text { conservation agents to } \\
\text { landowners }\end{array}$ & & & \\
\hline $\begin{array}{l}\text { Sommerville } \\
\text { et al. } \\
(2009: 2)\end{array}$ & required & & $\begin{array}{l}\text { positive } \\
\text { incentive }\end{array}$ & & & & $\begin{array}{l}\text { consideration of } \\
\text { additionality }\end{array}$ & \\
\hline $\begin{array}{l}\text { Milder et al. } \\
(2010: 1)\end{array}$ & & & & & $\begin{array}{l}\text { direct payments by } \\
\text { beneficiaries to land } \\
\text { stewards and indirect } \\
\text { payments earned through } \\
\text { eco-certified production }\end{array}$ & & & \\
\hline $\begin{array}{l}\text { Muradian } \\
\text { et al. } \\
(2010: 1205)\end{array}$ & & & $\begin{array}{l}\text { monetary } \\
\text { or non- } \\
\text { monetary }\end{array}$ & & between social actors & & & $\begin{array}{l}\text { with social } \\
\text { interest }\end{array}$ \\
\hline $\begin{array}{l}\text { Karsenty } \\
(2011: 1)\end{array}$ & required & $\begin{array}{l}\text { beneficiary and } \\
\text { provider }\end{array}$ & & & beneficiary to provider & & & \\
\hline $\begin{array}{l}\text { Porras et al. } \\
(2013: 7)\end{array}$ & required & $\begin{array}{l}\text { only on the } \\
\text { provider side }\end{array}$ & & & $\begin{array}{l}\text { NGO, private party, local } \\
\text { or central government } \\
\text { entity to provider }\end{array}$ & & & \\
\hline $\begin{array}{l}\text { Tacconi } \\
(2012: 35)\end{array}$ & required & $\begin{array}{l}\text { only on the } \\
\text { provider side }\end{array}$ & $\begin{array}{l}\text { provision } \\
\text { of } \\
\text { incentives }\end{array}$ & required & $\begin{array}{l}\text { only the ES provider as } \\
\text { payment receiver } \\
\text { mentioned }\end{array}$ & & $\begin{array}{l}\text { additional provision } \\
\text { of ES }\end{array}$ & \\
\hline $\begin{array}{l}\text { Smith et al. } \\
(2013: 13)\end{array}$ & required & & & & $\begin{array}{l}\text { individuals, communities, } \\
\text { businesses or governments } \\
\text { acting on behalf of } \\
\text { providers }\end{array}$ & & & \\
\hline $\begin{array}{l}\text { Engel } \\
(2015: 133)\end{array}$ & required & $\begin{array}{l}\text { voluntary for } \\
\text { providers }\end{array}$ & $\begin{array}{l}\text { positive } \\
\text { economic } \\
\text { incentive }\end{array}$ & & & & & \\
\hline $\begin{array}{l}\text { Wunder } \\
(2015: 241)\end{array}$ & required & $\begin{array}{l}\text { ES users and } \\
\text { providers }\end{array}$ & & & user to provider & & & \\
\hline $\begin{array}{l}\text { Davies } \\
\text { et al. } \\
(2018: 160)\end{array}$ & required & $\begin{array}{l}\text { ideally buyers } \\
\text { and sellers }\end{array}$ & & & $\begin{array}{l}\text { beneficiaries (citizens, } \\
\text { businesses, or governments } \\
\text { acting on their behalf) to } \\
\text { provider }\end{array}$ & & $\begin{array}{l}\text { additionality is } \\
\text { given }\end{array}$ & \\
\hline
\end{tabular}

features of the definitions are systematically compiled in Table 1. The original definitions are available in Appendix 1.

\section{Ex-ante criteria}

One of the main criteria of PES is the use of positive incentives for landowners that in return provide ES. In theory, the payment level refers to the providers' willingness to accept, which strongly corresponds with direct costs for ES provision as well as with opportunity costs (Ferraro 2008); however, in practice the payments often do not cover these costs (Kosoy et al. 2007, Kosoy and Corbera 2010). Even though only four definitions highlight this criterion directly, the other definitions include it implicitly. Thus, PES can be clearly distinguished from other economic environmental policy instruments that build on negative incentives meaning that ES providers get monetarily punished for the non-provisioning of ES. This is the case for Pigou taxes that build on the polluters pay principle in contrast to the stewards earn principle (Gómez-Baggethun and Ruiz-Pérez 2011). Although most PES schemes build on monetary incentives, some authors highlight the opportunity of in-kind payments, which are, however, rare in practice (Sommerville et al. 2009).
Conditionality is the key criterion of most definitions (11 out of 13 evaluated definitions) and "makes PES the frontrunner of a new paradigm of contractual conservation" (Wunder 2015:241). Conditionality means that payments to ES providers are only made if the provision of the ES can be contractually secured, making clearly defined and enforced property rights and good monitoring necessary (Engel 2015, Wunder 2015). The literature hints at several distinctions between conditionality types. Most prominent is the differentiation between input or action-based and output or performance-based conditionality (Matzdorf et al. 2013, Reutemann et al. 2016). The former focuses on generally environmentally friendly land-use actions that are assumed to secure some ES, while the latter refers to individually measured ES. In practice, input conditionality is much more common (Martin-Ortega and Waylen 2018). This is due to the easier and cheaper monitoring of compliance, while the measurement of direct ES flows is often challenging (Lima et al. 2017).

The notion of well-definition of ES, as mentioned in Wunder's primary definition, is strongly connected with the conditionality criterion, because for an explicit monitoring of ES a 
quantification is essential, especially in the case of outputconditionality (Wunder 2005). However, Corbera and colleagues (2007) point out that operating PES programs are often based on ill-defined ES.

Voluntariness is another often named key feature of PES definitions. Full or partial voluntariness is included in eight out of the 13 analyzed definitions. In the Coasean conceptualization, voluntariness optimally applies to both providers and beneficiaries of ES (Wunder 2005, 2015). As in a market, the involved parties can decide independently if they want to sell or respectively buy the commodified ES. In such cases the program is purely voluntary. However, PES schemes can also be (partly) involuntary. In such cases they are rather "driven by compliance regulation, both on the demand or the supply side" (Sattler and Matzdorf 2013:3). In practice, involuntariness on the providers' respectively buyers' side occurs mostly because of governmental interventions (Schomers and Matzdorf 2013).

The directness of transfer is related to the actors involved in the transaction. Whereas in the Coasean conceptualization the transfer goes from the beneficiary directly to the providing actor (e.g., Wunder 2015), in a Pigouvian view payments can also be generated by public sources or actors that do not directly benefit from the ES provision (Schomers and Matzdorf 2013). The directness of transfer is often subdivided into user- versus government-financed PES schemes (Van Hecken et al. 2012, Sattler and Matzdorf 2013, Wunder 2015). Unlike Wunder's definition, Corbera et al. (2007) describe PES as mostly government-funded, thus not being fully voluntary. National and international CSOs can also play a crucial role, whether as intermediary or as ES provider or buyer (Sattler et al. 2013, Grima et al. 2016). We found one definition that includes ecocertification as a form of indirect payment (Milder et al. 2010). Only two of the 13 definitions name direct payments from ES users to providers as a key feature (Karsenty 2011, Wunder 2015). Wunder's definition from 2005 uses the term buyer instead of user or beneficiary. However, based on the further details in his publication it can be concluded that this definition primarily focuses on ES users. In his later definition (2015) this criterion is substantiated.

Tacconi (2012) adds transparency as a further important definition criterion. Kolstad and Wiig (2009), as cited in Tacconi (2012) define transparency "as the timely and reliable provision of information to all relevant stakeholders" (Tacconi 2012:33).

\section{Ex-post criteria}

Whereas the ex-ante criteria address the policy instrument design, the ex-post criteria identified in four definitions focus on the aims of PES programs. Sommerville et al. (2009), Tacconi (2012), and Davies et al. (2018) posit additionality as an important criterion. Additionality can only be verified in retrospect and means that "ES benefits (or proxy land use practices) are over-and-above the baseline (or business-as-usual) level, and do not lead to the loss or degradation of ES elsewhere" (Davies et al. 2018:160). Thus, additionality is closely connected to conditionality.

Muradian et al. (2010:1205) include also welfare gains in their definition by using the term "social interest." In this view, social justice and poverty alleviation are, besides environmental additionality, important goals of PES schemes (Van Noordwijk and Leimona 2010, Shelley 2011). This criterion is difficult to assess, both because of its normative character, which depends to a large extent on the chosen principle of justice, and difficulties regarding social impact evaluation (Wunder 2015). However, in the literature, PES are often highlighted as a win-win approach, reducing poverty and ecosystem degradation simultaneously (Pagiola et al. 2005, Muradian et al. 2013).

\section{Spatial scales matter and need to be set in context with the diversity of definitions}

The role of spatial scales for the environmental and social effectiveness of PES programs has not been sufficiently examined in the literature; most of the 40 papers detected as eligible rarely touch upon the issue of spatial, or geographical, scales. However, spatial scales play a crucial role in science and politics because scientific analyses that study and measure processes or objects, as well as political actions, prominently refer to specific scales (Gibson et al. 2000). Observed phenomena at one scale are often not generalizable for other scales, making a careful consideration of scale aspects necessary, especially against the background of a globalized world.

One often mentioned issue addresses the distinction between the scale of ES provision versus the scale of ES benefits. Whereas ES accrue locally, the scale of direct benefits from the provided services is largely dependent on the ES type (den Uyl and Driessen 2015). Therefore, Farley and colleagues (2010:2075) state: "[a] serious obstacle [for conservation] ... is the fact that ecosystem services provide benefits at a variety of spatial scales, ranging from the local to the global." For example, pollination services are usually distributed locally, water-related services are spread over local or regional scales, whereas the benefits of carbon sequestration services are globally distributed (Corbera et al. 2009, Kemkes et al. 2010, Banerjee et al. 2013, Kull et al. 2015). Thus, within PES programs, the scale of benefits should be considered carefully, because "understanding the spatial distribution of ecosystem services is key to identifying potential beneficiaries, the institutions required to provide the service and the transaction costs associated with provision" (Kemkes et al. 2010:2072). Referring to Wunder's definition (2015), the funding source depends directly on the scale of ES benefits, because payers are ES beneficiaries/users by definition. In contrast, this is not the case for definitions that mention agents who do not directly use ES as potential ES buyers. Thus, clarity regarding the underlying definition is central when discussing scale aspects of PES programs. Only broader definitions include large international programs (IPES), except for programs addressing globally distributed carbon ES. Other ES types can only indirectly provide large-scaled international benefits, e.g., by securing the production of agricultural goods that are traded globally.

Some authors emphasize cross-scale mismatches between ecological and social processes as a "key challenge in socialecological systems"(Cerra 2017:595). These mismatches find their expression, for example, in scale differences between ecosystem management, ecological processes, and the spatial payment levels (Reed et al. 2014). In addition, the sphere of managing institutions and the jurisdictional scale rarely match the targeted environmental area, which calls for a better consideration of potential mismatches when designing PES programs (Meadowcroft 2002, Corbera et al. 2009, Loft 2011, Van der Horst 
2011, den Uyl and Driessen 2015, Huber-Stearns et al. 2017). However, rearrangements or new formations of institutions and especially of land tenure in order to solve these scale-mismatches can also lead to problems, because they bear the risk of unhinging well-functioning local governance structures (Favretto et al. 2016, Reed et al. 2017).

Many authors argue that local and regional schemes provide a range of advantages compared to national or international schemes. There are indications that local scale PES programs are more effective (Agrawal et al. 2014, Grima et al. 2016). Scholars explain this, for example, with the incorporation of local and/or indigenous knowledge, which would allow for a better identification of appropriate actors as well as costs and benefits (Grima et al. 2016, Paudyal et al. 2016). Local knowledge arguably eases decision and policy making and potentially increases the social learning of the PES participants, which creates opportunities for a collective management of resources (Lockie 2013, Grima et al. 2016). This, together with an easier identification and matching of buyers and sellers (OECD 2013), has the potential to lower the transaction and enforcement costs significantly. Some authors argue that also in case of globally distributed benefits it is reasonable to incorporate beneficiaries as locally as possible to guarantee low transaction costs (Kemkes et al. 2010, Thompson 2018). On the other hand, this incentivizes free-riding at the global scale (Farley et al. 2010, OECD 2013). Local schemes are promising also because of the stakeholders' motivation to participate in PES programs as well as because the ES appreciation tends to increase with a smaller distance to the location providing ES (den Uyl and Driessen 2015, Thompson 2018). In general, given a preference for local PES schemes, it is important for the setup of programs to get the appropriate actors involved (Lockie 2013). This can lead to a trade-off between getting enough participants involved, while being as local as possible (Banerjee et al. 2013, Lockie 2013, Sorice et al. 2018).

In practice, most PES schemes operate at local or regional scales anyhow, while international PES programs appear to be rare. Nevertheless, there are also numerous authors, who argue for an upscaling of PES schemes to maximize the conservation of ES, even though "national government PES programs entail large and complex governance structures involving multiple sequential implementation steps at different geographic scales" (Ezzine-DeBlas et al. 2016). It can be assumed that this also applies to international PES programs. Especially regarding carbon ES, this upscaling tendency is observable and promoted by global institutions such as the World Bank, as is the case for the international program "Reducing Emissions from Deforestation and Forest Degradation" (REDD+), which is seen by some scholars as the largest operating PES experiment worldwide (McElwee et al. 2014, Corbera 2012). To make national and international programs work, some authors call for cross-scale linkages between existing organizations and institutions at different scales, rather than implementing a new governance structure (Corbera et al. 2009, den Uyl and Driessen 2015, Cerra 2017). In such polycentric governance frameworks, intermediaries, often from the civil, public, academic, or private sector, play a central role in connecting different scales (Huber-Stearns et al. 2013, Cook et al. 2016, Schröter et al. 2018). However, the upscaling of PES schemes remains challenging, because, for example, the upscaling of ES valuations exacerbates existing uncertainties (Kull et al. 2015). Additionally, in large-scale programs, private fundraising becomes difficult, which is why those programs are often governance-financed (den Uyl and Driessen 2015). Furthermore, higher levels imply an increasing number of potential stakeholders, making the consideration of various interests challenging yet evermore necessary (Schleyer et al. 2015).

Last, environmental additionality gained at one place can be defeated by environmental destructions occurring elsewhere instead, which is called leakage effect (Engel and Muller 2016). The reverse outcome is also possible: spillovers can enhance conservation at other locations because of changes of social norms, increased ecotourism opportunities, or the strengthening of laws (Pattanayak et al. 2010). However, today's long and globally connected production chains are difficult to oversee, making it complicated to analyze the causes and drivers of environmental change (Friis et al. 2016).

\section{PES programs are criticized from various angles}

Critique of PES schemes is manifold and depends largely on the authors' backgrounds. The systematic literature review, which led us to 29 eligible publications, pointed out different schools of thought or movements criticizing the PES approach. However, it must be taken into account that the inductive literature search focusing on the politically highly controversial term "neoliberal" as well as the term "neoclassical" narrows the view on the variety of critique.

Environmental economics provide the theoretical grounding for the PES approach. This school of thought is strongly influenced by neoclassical theory and follows the assumption that environmental degradation is a result of market failures, namely the exclusion of environmental costs in product prices (Scales 2015). Hence, environmental economists recommend the implementation of valuation and commodification techniques to internalize externalities (Perman et al. 2011). After reviewing the identified publications and clustering the different points of critique, we conclude that many critics can be assigned mainly to two academic fields: ecological economics and political ecology. Ecological economists are especially interested in the interdependencies between ecology and economy, based on the approach of strong sustainability, assuming that natural capital cannot be substituted by any human-made capital (GómezBaggethun et al. 2010). In contrast, political ecology addresses the underlying structures of capitalism and power with regard to the commodification of nature. Political ecology has its roots in various fields such as rural critical geography, sociology, and anthropology, and is influenced by, for example, Marx's value theory and egalitarian thoughts (Kallis et al. 2013, Huber 2017). The assignment of the identified arguments, publications, and authors to these groups is not always clear-cut, as the academic fields themselves show overlaps. However, we are convinced that keeping these academic fields in mind helps to better understand the argumentation structures behind the critique.

\section{Critique of the neoliberal patterns of the PES approach}

PES are often described as part and expression of a broader neoliberal agenda that follows a logic of accumulation and economic growth. Critics see PES in line with the global diffusion of a neoliberal narrative within the last decades, arguing "that the [PES] approach implicitly accepts neoliberal capitalism as both 
the problem and the solution to the ecological crisis" (Fletcher and Büscher 2017:224). Fletcher and Büscher call this "the PES conceit." This so-called "neoliberal conservation" or "green neoliberalism" (Büscher et al. 2012, Fletcher and Büscher 2017), it is argued, pushes the valuation and commodification of nature forward, building on the assumption that monetary incentives are the best way for governing human behavior (Allen 2018, Fletcher 2010).

The term "neoliberalism" itself is controversially discussed. Some authors deny that PES programs are a neoliberal tool, since only very few PES schemes can be described as markets for ES grounded in competition (McElwee et al. 2014, Matulis 2017, Van Hecken et al. 2018). Others describe PES as a neoliberal instrument, even though most PES schemes rather masquerade as markets (Matulis 2017). They justify their conviction by drawing on Foucault's theory of governmentality elucidating "a process of repeated practice and inscribed procedure, through which complicit assumptions and behavioral codes become routine" (Wynne-Jones 2014:149). Regarding PES this means that symbolic meanings such as the monetary valuations of ES aimed at gaining attention for ES protection are often forerunners of the commodification and marketization of ES (Fletcher and Büscher 2017). This is explained by monetary incentives, whether based on true markets or not, introducing a neoliberal thinking in commodities and exchange values. Foucault's governmentality is strongly connected with the term "performativity," which describes how language, thoughts, and narratives shape concrete actions (Kolinjivadi et al. 2017). Thus, neoliberalism is understood as a process rather than as an outcome. Because most PES schemes are hybrid instruments incorporating both marketlike and regulatory instruments through state intervention, some scholars use alternative terms such as "hybrid neoliberalism" (McCarthy 2005, McAfee and Shapiro 2010) or "social neoliberalism" (Cerney et al. 2005). All in all, an allocation of PES in the neoliberalism discourse becomes difficult because of the diverse definitions of PES as well as the term "neoliberalism." For providing an analytical basis for the degree of neoliberalization of PES programs, the discussion of various levels of commodification could be useful (Muradian et al. 2010, Gómez-Baggethun and Ruiz-Pérez 2011, Hahn et al. 2015).

\section{Critique of the monetary valuation and commodification of ES}

The valuation of ES in monetary terms as well as the expression in exchange values is central to many publications criticizing PES. This major field of critique is to be seen as a cross-sectional theme touching fields of critique in the social as well as in the ecological sphere and can be referred to all PES definitions. Generally speaking, values describe and rank "the importance of actions" (Graeber 2001:49) and "are embedded in, and reproduced through social exchange" (Allen 2018:244). Monetary valuation is only one of many types of valuation. Scholars criticize that monetary valuations follow a market thinking, which is based on the prioritization of exchange values over use values (Scales 2015), thereby following an understanding of weak sustainability in which ecosystem services and functions can be substituted with other ES or even human-made capital (Biely et al. 2018). Following this line, critics argue that monetization supports a utilitarian rationality and a pure interest in profit-maximization, which abets the view on economic agents as "homo economicus" (McAfee 2012, Kull et al. 2015, Van Hecken et al. 2018). Ignoring other valuation languages is said to neglect alternative rationalities such as intrinsic, fundamental, eudaemonistic, and instrumental values of nature (Muniz and Cruz 2015). Thus, the articulation of ES in exchange values undermines "the social complexity necessary for sustainability" (Allen 2018:253). Therefore, many scholars plead for a plurality of values in the context of nature conservation (Kallis et al. 2013, Muniz and Cruz 2015). If value plurality is not considered, a potential crowdingout of intrinsic motivations is often mentioned as a barrier for successful nature conservation (Corbera 2012, Hahn et al. 2015, Scales 2015). The result could be that "the willingness to accept will be more enticing than the willingness to change" (Muniz and Cruz 2015:10911). However, whether PES result in crowding-out or crowding-in seems strongly dependent on the incentive type, namely, truly monetary or rather in-kind incentives, as well as on the social and cultural background of the participating agents (Rode et al. 2015).

Various critics argue that the monetization of ES goes together with a commodification of ES and describe these tendencies as, for example, "commodity fetishism" (Kosoy and Corbera 2010) or "complexity blinder" (Norgaard 2010). Consequently, these simplifications would conceal the complexity and interconnectedness of ecosystems, for example when some PES programs focus on carbon ES while excluding other important ES (Kallis et al. 2013). When commodifying ES, the problem is identified that nature "is not produced specifically for the purpose of exchange" (Scales 2015:228). Thus, the exchange is often based on incomplete and contested ES commodification (McElwee 2012), which is formatted "through the creation of new institutions and technologies" (Scales 2015:228). Necessary enabling conditions for the exchange are commodities with clear boundaries and values as well as clearly defined property rights, conditions that can rarely be guaranteed and that often differ between ES types, regions, and cultures (Kosoy and Corbera 2010, Scales 2015). The commodification of ES is further complicated by many ES resisting to be commodified because of their public good or commons character (Bakker 2003). Therefore, PES programs run into the danger of rather focusing on ES that are easy to commodify, such as carbon ES, instead of integrating complex bundles of ES into the schemes.

The underlying valuation methods are also viewed critically because the measurement and calculation of ES is often difficult, e.g., due to incomplete information and scientific uncertainties regarding ecosystem functioning (Muradian et al. 2010, McAfee 2016). Scientific uncertainty applies also to the relationship between ES provision and land use practices as well as to socialecological systems more generally (Lima et al. 2017). A further problem is related to the additionality of PES programs. In practice, it is very challenging to verify whether or not a sustainable land use practice would have been implemented in the absence of PES anyhow (McAfee 2016). This becomes even more difficult when considering the aforementioned leakage effects.

\section{Critique regarding social and institutional aspects}

Many scholars criticize PES and their neoliberal character for reinforcing social inequalities. Although PES are often acclaimed as a potential win-win approach reaching important ecological and equity goals simultaneously, various authors argue that the implemented PES programs rarely consider important aspects of 
environmental justice (Kosoy and Corbera 2010, Muradian et al. 2010, Muradian et al. 2013, Muniz and Cruz 2015, Fletcher and Büscher 2017). Different dimensions of justice are mentioned in the literature, which are often unaddressed by PES schemes, such as distributional, procedural, and participatory justice as well as justice of recognition and of capabilities (Muniz and Cruz 2015). Taking these different dimensions of justice into account, PES arguably produce winners and losers (Blanchard et al. 2016), which some critics explain with the effects of a neoliberal market logic and the related consequences of performativity and governmentality (Fletcher and Büscher 2017).

Many scholars assume that inequalities are a result of the underlying power structures and power imbalances, which are paid too little attention in the implementation process of PES programs. This cluster of critique follows often a political ecology thinking. Power imbalances find their expression already in the valuation process, because institutions and power structures shape the monetary valuation of ES (Kallis et al. 2013). In the case of already implemented PES programs, power imbalances find their manifestation in inequalities between the different actors. In many publications, the disempowerment of local people is considered central. A study by Cavanagh and Benjaminsen (2014) focuses on the attempted establishment of a carbon market in Uganda, which led "to the eviction of the local people, without any compensation for their loss of land, property, and livelihoods" (Matheus 2018:31). The influence of experts and of unelected institutions such as CSOs increases in these cases, which could then influence decisions at the expense of the local people (Corbera 2012, Apostolopoulou et al. 2014). Often, elite interests become dominant (Roth and Dressler 2012), while interests of disadvantaged people or those with a traditional lifestyle are ignored (McElwee 2012, Muniz and Cruz 2015). Additionally, because privatized land is often seen as an important precondition for the implementation of PES programs, people holding formal land titles, i.e., people who are anyhow wealthier than others, are advantaged during PES implementation (Corbera 2012). These different concerns are often accompanied by a lack of participatory and procedural justice in PES programs. Therefore, some authors call for the development of participation methods to better recognize the perceptions of local people (Petheram and Campbell 2010, Corbera 2012, Bétrisey et al. 2016). Some scholars see also risks of depoliticization and a weakening of democratic structures when responsibilities move from governments to the market sphere (Swyngedouw 2000).

On a global level, critics highlight that the compensation logic of PES potentially increases North-South inequalities and fosters rebound effects. However, these arguments against PES follow an understanding of internationalized PES programs and contradict the current manifestation of mostly local or regional schemes. Therefore, it is once more important to consider the variety of PES definitions. Currently, this debate is particularly relevant for carbon ES, e.g., in the context of REDD+, and for other programs that generate their funding globally, while the direct ES benefits are distributed at a local level. Although one could assume that the voluntary entering of PES programs by and the additional financial resources for the ES providers leads to an increase of the sovereignty of Global South countries as well as of local communities there, critics argue that PES schemes might undermine sovereignty when the economically powerful countries of the Global North and international organizations such as the World Bank shape the implementation process because of prevailing power imbalances, thereby leading to a reinforcement of (neo-)colonial logics (Muniz and Cruz 2015, Matheus 2018). Moreover, the disparities between these countries might be reinforced because of the lower opportunity and offset costs of poorer Global South countries, where compensations take place accordingly. This problem is known as "the poor sell cheap" principle (Martínez-Alier 2002, 2014). It implies that the compensation logic might exacerbate North-South inequalities and lead to rebound effects in Global North countries, because compensation schemes give consumers a justification for sustaining their resource-intense lifestyle (Muniz and Cruz 2015). Additionally, scholars point out the danger of so-called "green grabbing" because PES programs might lead to an increasing competition for property rights on valuable ES-providing land (Fairhead et al. 2012, Van Hecken et al. 2015).

Overall, the different schools of thought highlight different points of criticism. Whereas ecological economists put a specific focus on the value debate, political ecologists stress the underlying power structures and inequalities, but their criticism often converges. However, it is important to consider that even within one research tradition the views on PES can vary. Furthermore, our review indicates that, particularly over the last years, degrowth proponents developed rather PES-critical positions (e.g., Muniz and Cruz 2015). Degrowth scrutinizes the predominant economic growth-paradigm in economy and politics, the feasibility of decoupling GDP-growth and resource consumption, as well as the hegemonic understanding and measurement of prosperity (D'Alisa et al. 2016, Parrique et al. 2019). Degrowth conceives an alternative economy that is based on a new understanding of welfare. However, a clear position on PES cannot be derived from this perspective, especially because not all degrowth proponents strictly reject market-based conservation instruments (Petschow et al. 2018).

\section{DISCUSSION}

This literature review revealed important information about the diversity of PES understandings, about the importance of considering spatial scale impacts on PES program effectiveness, and about various points of critique of this still novel conservation instrument. In the following, we will highlight three important issues: the need for a clear definition basis, the role of the globalized economy for PES, and the potentials of collective action for a successful design of PES programs.

\section{Analytical research needs a clear definition basis}

The high diversity of PES definitions potentially leads to confusion and misalignment of expectations both in science and for practitioners. A probable reason for these different understandings lies in the various disciplinary backgrounds of the proponents of those definitions. Possibly, also the popularity of this tool in politics leads to a broadening of the concept because it holds an incentive to label different instruments as PES, e.g., to increase chances of funding. This broadening of the concept is not all negative, because it introduces various perspectives on PES that raise new questions, for example, regarding better connections between ecological and social aims. However, for empirical analyses of PES schemes a clear conceptual basis and the development of a common understanding between the 
stakeholders, both in science and in practice, is important, as has been emphasized by Martin-Ortega and Waylen (2018).

Because the definitions differ regarding the question of whether payers for ES must also be direct beneficiaries of these ES, clarifying definitions is important for studying the scope and success of schemes as well as any socioeconomic effects. Furthermore, as the various PES definitions differ in terms of market-closeness and levels of commodification of PES programs, different points of critique apply in each case. The definitions by Wunder (2005) and Muradian et al. (2010) especially show huge differences regarding these questions. Therefore, the diversity of understandings complicates the debate about the success of PES programs, both from an ecological as well as from a social perspective.

Not only PES but also ES themselves are disparately defined. Many authors refer to the definition of the Millennium Ecosystem Assessment stating that ES "are the benefits people obtain from ecosystems" containing also "provisioning services such as food, water, timber, and fiber" besides further regulating, cultural and supporting services (Millennium Ecosystem Assessment 2005:V). However, Danley and Widmark (2016), for example, show the great diversity of ES understandings existent in the literature and carved out that they build on three connected and overlapping concepts: "... the physical components of the ecosystem (structure), ... the functioning of and interaction between those components (process or function), ... and the resulting contribution to human welfare from the ecosystem (benefit or benefit-providing service)" (Danley and Widmark 2016:134). Thereby, they highlight the natural science view on ES by referring, for example, to Daily (1997). She highlights the functions and processes of a specific ecosystem structure when defining ES as "conditions and processes through which natural ecosystems, and the species that make them up, sustain and fulfill human life" (Daily 1997:3). Also Farley and Costanza (2010) refer to ecosystem functions and processes based on a particular ecosystem structure, when calling for a differentiation between on one hand stock-flow resources that are harvestable at a specific rate and physically convertible, the ecosystem goods, and on the other hand only qualitatively changeable fund-services that "are a particular type of flow, or flux, generated by a particular configuration of stock-flow resources," the ecosystem services (Farley and Costanza 2010:2062). According to this definition, building on the flow-funds model by Georgescu-Roegen (1971), the Millennium Ecosystem Assessment definition of provisioning services refers to stock-flow resources rather than to any services. In contrast, the economic view focusing on natural capital defines ES merely as "ecological things or characteristics, not functions or processes" (Boyd and Banzhaf 2007:620). Such differing views on ES also influence the understandings of what PES are and which designs are most suitable to tackle the problem of ES degeneration. In particular, the natural science view seeing ES as processes and functions leads to the conclusion that many ES can be compared to public or quasi-public goods (Diswandi 2017), inasmuch they are resistant to classical commodification processes because they are non-rival and non-excludable. This might lead to major confusion in the debate of whether PES are forerunners of commodification processes or not.
We agree with defining ES as fund-services. However, we argue that PES designs in practice often use proxies for evaluating and valuing the current state of ES. These proxies help to create a certain degree of excludability and rivalry on ES with public or common good characteristics. Thus, PES might increase commodification processes by raising funding on the beneficiaries' side for particular ES proxies, e.g., water quality as a proxy for the capacity of the ecosystem to purify water. For example, Coasean-like PES programs are based on private funding to pay providers of ES using proxies to measure the quality of these services. The price is then determined in the bargaining process. It is important to acknowledge, however, that such bargaining and valuation processes are also part of government-paid PES schemes, even though a market with various sellers and buyers is not existent in this case. ES proxies are usually not classical economic goods because they are not discrete and physically transformable entities. Instead, in these cases "fictitious commodities" (Polanyi 1957) play a central role: "Because most PES schemes often rely on external assessments of the value of these environmental services to birth the commodities that can be traded and sold, such constructions are similar to what Polanyi deemed, fictitious commodities' in that they do not exist in-toto, but must be created, resulting in commodification that is always incomplete and contested (Polanyi, 1957, p. 76)" (McElwee 2012:414). Another example for such fictitious commodities is the creation of $\mathrm{CO}_{2}$ certificates and a market trade of such certificates that is coupled with the $\mathrm{CO}_{2}$ sequestration and storage capacity of forests. Additionally, already marketed ecosystem goods (stock-flow resources) can be used as ES-proxy carrier, for example, by applying ES proxyrelated price premiums on eco-certified timber from sustainable sources. However, there are differing views existent whether price premiums can be counted as PES or not (Hahn et al. 2015). Generally, it remains challenging to raise private funding for ES proxies, for example, because imposing full excludability for ES is seldom possible. Therefore, free-rider problems might hinder the motivation of ES beneficiaries to pay. Furthermore, the scarcity of those services is often not obvious because the negative consequences of ES degradation are often not directly visible, but rather in the long run. In an economic system, where short-term profits play an important role, the values of such ES get discounted, which diminishes funding sources. Here we see one reason why government-paid PES programs are so common.

Following the view of ES as fund-services, we highlight three central aspects that ease the distinction of PES programs from other environmental policy instruments. First, we see the use of positive incentives, monetary or in-kind, as an inevitable key criterion of PES. Second, contractual conditionality is central to PES and strongly coupled with monitoring practices that either focus on measurable proxies for the quality of ES or on specific land use practices and changes, where an increase of ES benefits can be assumed. This implies that various levels of ES commodification are imaginable depending on the ES type in focus, as well as on the chosen PES design. Third, entering the conditional PES contracts must be voluntary, at least on the ES providing side. We forego the criterion of full voluntariness to include also governmentally paid programs and to consider various actor constellations reaching from market-close to less 
market-based programs, recognizing that the term "marketbased" remains fuzzy in the literature. If ES providers are monetarily compensated for abiding by legal obligations for ES protection, we do not consider these payments as PES, but rather as compensations for legal restrictions. Furthermore, our definition leaves open whether ES buyers have to be direct beneficiaries or not because this criterion is more likely to cause ambiguity than clarity, given the different characteristics of the various existent ES regarding, for example, their spatial location.

These criteria provide the necessary balance between the precision required for empirically testing hypotheses, for example, regarding the effectiveness of PES programs, and the openness needed to integrate the various PES design approaches that we find in practice. We share Wunder's (2015) view that ex-post criteria are not useful for a typology of PES programs because such features do not focus on the PES design but on the resultant social and ecological effectiveness.

\section{Evaluating PES in the context of the globalized economy}

Our review of scale-related issues in PES points to a great need to deepen the research about the connections and influences of the globalized economy with regard to PES program effectiveness. Some important issues have already been stressed in this review, namely, the debate about local versus up-scaled PES schemes, challenges related to leakage effects, and the existence of inequity aspects that arise, for example, from the North-South disparities in the case of international PES programs. However, it is rarely discussed how local, regional, and global scales can be linked within PES programs, while considering equity and ecological aspects as well. One exception are Farley and Costanza (2010), who, regarding the implementation of multiscale IPES, state that "mutually reinforcing institutions at local, regional and global scales over short, medium and long time scales will be required. Institutions should be designed to ensure the flow of information between scales, to take ownership regimes, cultures, and actors into account, and to fully internalize costs and benefits" (Farley and Costanza 2010:2061). A challenge lies in the development of just schemes guaranteeing the engagement of all stakeholders at all scales and sustainable and fair funding structures. To refine successful multiscale PES schemes, it could be helpful to compare existing PES schemes at various scales regarding different ecological and distributional criteria. Furthermore, it would be interesting to draw linkages between the PES and the telecoupling approach that focuses on distal connections and feedbacks shaping current land use changes (Friis et al. 2016). Other scale aspects such as the temporal dimension should also be addressed in the future.

\section{Rediscovering the strengths of collective action in the context of PES}

In our view, land tenure regimes should receive greater consideration in PES research. Many critics argue that PES reinforce commodification and thereby privatization tendencies, which potentially lead to social conflicts depending on the underlying power structures (Vatn 2010). The PES criteria we distilled from prevailing definitions focus particularly on the ES providers' side and underline their voluntary signing of PES contracts. This implies that PES schemes need owners of ES providing land, who possess a bundle of ownership and disposal rights that allows them to decide how to use their land, whether they secure ES and receive PES in return or manage their land without a focus on ES securing management practices. Different authors highlight that these rights are often assigned to private (legal) persons, which supports the advancing privatization of land (Porras et al. 2008, Vatn 2010, Gómez-Baggethun and RuizPérez 2011, McElwee 2012). The review revealed that privatizations can have negative social implications, for example, the displacement of local and poorer land users by wealthier people that have both money and power to acquire land titles (Cavanagh and Benjaminsen 2014, Scales 2015). In this regard, the interactions between PES effectiveness and the design of the rights of disposal as well as the question of who owns the property rights for the ES providing ecosystems is of key interest, but still insufficiently studied.

Debates about PES often fall short of the fact that PES can be based on private-individual or on common property (Farley and Costanza 2010). This issue affects especially the question of how the local actors are coordinated and how the different types of property rights, such as management, access, or withdrawal rights, are distributed at the relevant levels of governance (Schlager and Ostrom 1992). Hence, there is potential to connect PES with the commons debate. Ostrom (1990) describes how commons have been successfully managed for centuries. Particularly, she highlights the advantages of interlaced and complex local governmental systems that allow for a direct participation and cooperation of citizens instead of centralized state interventions or privatizations of commons. However, three decades later, private property rights are even more popular in the debate about environmental policy instruments.

We call for a shift in focus toward local collective governance, also in the context of PES. An increasing number of research activities now address so-called collective or community-based PES programs that aim at incentivizing the protection of ES for communities that own land under common property rather than for individual, private land owners (Muradian 2013, Hayes et al. 2017, Brownson et al. 2019, Hayes et al. 2019). Such collective PES schemes provide a promising opportunity for successful nature conservation that is potentially less dependent on privatizations. In the literature, various advantages of such collective PES programs are mentioned already, such as the lowering of transactions costs, the improvement of the local social capital when supporting collective community governance, or greater distributive justice (Nieratka et al. 2015, Narloch et al. 2017, Brownson et al. 2019). However, evidence of a potentially greater social as well as ecological effectiveness of collective PES is scarce, contradictory, and highly context dependent (Gatiso et al. 2018), which makes clear statements about the success of such collective schemes difficult. In order to analyze whether and under which circumstances collective PES are successful, we argue that it is important to analytically differentiate between individual and collective PES in the context of the diversity of the existing definitions. Furthermore, we see an urgent need for in-depth research on whether collective PES could be an opportunity to de-neoliberalize and de-commodify PES or whether they are still just another forerunner of expansive commodification, privatization, and commercialization of ecosystems. In this context, we also see the necessity for a scientific debate about the design of contractual conditionality, especially whether the payments are linked with well-defined and commodified ES 
(proxies) or only with bundles of ES by coupling payments with specific land use practices, which are tested for their ES securing effects from time to time. Therefore, the design of conditionality, as well as the form of the payment negotiation processes, strongly affects the degree of commodification and the market-closeness within PES programs. In order to gain a better understanding of these issues it would seem important to systematically bring together various disciplinary perspectives and practitioners' knowledge in an inter- and transdisciplinary research mode.

\section{CONCLUSION}

The systematic literature review provided novel insights into the current state of PES research. The classification of existing definitions revealed that there is no common understanding of PES in the scientific community. The diversity of definitions should be considered when evaluating the success of PES programs, especially with regard to the influence of scale on program effectiveness. Similarly, the analysis of existing critique showed that different authors work with different PES definitions, which makes the comparison and juxtaposition of their findings difficult.

Future research should take the differences between existing PES definitions into account to ensure the comparability of results. The linkages of local, regional, and global scales should be considered for successful PES design and analysis. A re-focusing of research on common instead of private property rights could provide novel insights on and help enhance local and collective governance systems for a sustainable use of resources.

Responses to this article can be read online at: https://www.ecologyandsociety.org/issues/responses. $\mathrm{php} / 12307$

\begin{abstract}
Acknowledgments:
This publication was made possible with funding from a scholarship of the Heinrich Böll Foundation as well as from the Humboldt Research Track Scholarship, which is financed by HumboldtUniversität zu Berlin as part of the German Excellence Initiative of the federal and state governments. IRI THESys, too, was set up by funding from the Excellence Initiative. Furthermore, we acknowledge support by the German Research Foundation (DFG) and the Open Access Publication Fund of Humboldt-Universität zu Berlin. We thank the anonymous reviewers for their valuable comments that have considerably improved the quality of this manuscript.
\end{abstract}

\section{Data Availability:}

Datalcode sharing is not applicable to this article as no new datal code were created or analyzed in this study.

\section{LITERATURE CITED}

Agrawal, A., E. Wollenberg, and L. Persha. 2014. Governing agriculture-forest landscapes to achieve climate change mitigation. Global Environmental Change 29:270-280. https://oi. org/10.1016/j.gloenvcha.2014.10.001
Allen, K. 2018. Why exchange values are not environmental values: explaining the problem with neoliberal conservation. Conservation and Society 16(3):243-256.

Apostolopoulou, E., D. Bormpoudakis, R. Paloniemi, J. Cent, M. Grodzińska-Jurczak, A. Pietrzyk-Kaszyńska, and J. D. Pantis. 2014. Governance rescaling and the neoliberalization of nature: the case of biodiversity conservation in four EU countries. International Journal of Sustainable Development and World Ecology 21(6):481-494. https://doi.org/10.1080/13504509.2014.979904

Bakker, K. 2003. An uncooperative commodity: privatizing water in England and Wales. Oxford University Press, Oxford, UK.

Banerjee, S., S. Secchi, J. Fargione, S. Polasky, and S. Kraft. 2013. How to sell ecosystem services: a guide for designing new markets. Frontiers in Ecology and the Environment 11(6):297-304. https:// doi.org/10.1890/120044

Bétrisey, F., C. Mager, and S. Rist. 2016. Local views and structural determinants of poverty alleviation through payments for environmental services: Bolivian insights. World Development Perspectives 1:6-11. https://doi.org/10.1016/j.wdp.2016.05.001

Biely, K., D. Maes, and S. Van Passel. 2018. The idea of weak sustainability is illegitimate. Environment, Development and Sustainability 20(1):223-232. https://doi.org/10.1007/s10668-016-9878-4

Blanchard, L., C. Sandbrook, J. Fisher, and B. Vira. 2016. Investigating consistency of a pro-market perspective amongst conservationists. Conservation and Society 14(2):112-124.

Borja, A. 2015. Writing the first draft of your science paper - some dos and don'ts. Elsevier, Amsterdam, Netherlands. [online] URL: https://www.elsevier.com/connect/writing-a-science-paper-somedos-and-donts

Boyd, J., and S. Banzhaf. 2007. What are ecosystem services? The need for standardized environmental accounting units. Ecological Economics 63(2-3):616-626. https://doi.org/10.1016/j.ecolecon.2007.01.002

Brownson, K., E. Guinessey, M. Carranza, M. Esquivel, H. Hesselbach, L. M. Ramirez, and L. Villa. 2019. Communitybased payments for ecosystem services (CB-PES): implications of community involvement for program outcomes. Ecosystem Services 39:100974. https://doi.org/10.1016/j.ecoser.2019.100974

Büscher, B., S. Sullivan, K. Neves, J. Igoe, and D. Brockington. 2012. Towards a synthesized critique of neoliberal biodiversity conservation. Capitalism Nature Socialism 23(2):4-30. https://doi. org/10.1080/10455752.2012.674149

Cavanagh, C., and T. A. Benjaminsen. 2014. Virtual nature, violent accumulation: the 'spectacular failure' of carbon offsetting at a Ugandan National Park. Geoforum 56:55-65. https://doi.org/10.1016/j.geoforum.2014.06.013

Cerney, P., G. Menz, and S. Soederberg. 2005. Different roads to globalization: neoliberalism, the competition state, and politics in a more open world. Pages 1-13 in S. Soederberg, G. Menz, P. Cerny, editors. Internalizing globalization: the rise of neoliberalism and the decline of national varieties of capitalism. Palgrave McMillan, Hampshire, UK. https://doi.org/10.1057/9780230524439 1 
Cerra, J. F. 2017. Emerging strategies for voluntary urban ecological stewardship on private property. Landscape and Urban Planning 157:586-597. https://doi.org/10.1016/j.landurbplan.2016.06.016

Coase, R. R. H. 1960. The problem of social cost. Journal of Law and Economics 3:1-44. https://doi.org/10.1086/466560

Cook, D. C., N. P. Kristensen, and S. Liu. 2016. Coordinated service provision in payment for ecosystem service schemes through adaptive governance. Ecosystem Services 19:103-108. https://doi.org/10.1016/j.ecoser.2016.01.008

Corbera, E. 2012. Problematizing REDD+ as an experiment in payments for ecosystem services. Current Opinion in Environmental Sustainability 4(6):612-619. https://doi.org/10.1016/ j.cosust.2012.09.010

Corbera, E., N. Kosoy, and M. Martínez Tuna. 2007. Equity implications of marketing ecosystem services in protected areas and rural communities: case studies from Meso America. Global Environmental Change 17(3-4):365-380. https://doi.org/10.1016/j. gloenvcha.2006.12.005

Corbera, E., C. G. Soberanis, and K. Brown. 2009. Institutional dimensions of payments for ecosystem services: an analysis of Mexico's carbon forestry programme. Ecological Economics 68 (3):743-761. https://doi.org/10.1016/j.ecolecon.2008.06.008

D’Alisa, G., F. Demaria, and G. Kallis. 2016. Degrowth. Handbuch für eine neue Ära. Oekom-verlag, Munich, Germany.

Daily, G. 1997. Introduction: what are ecosystem services? Pages 1-10 in G. Daily, editor. Nature's services: societal dependence on natural ecosystems. Island, Washington, D.C., USA.

Danley, B., and C. Widmark. 2016. Evaluating conceptual definitions of ecosystem services and their implications. Ecological Economics 126:132-138. https://doi.org/10.1016/j. ecolecon.2016.04.003

Davies, H. J., K. J. Doick, M. D. Hudson, M. Schaafsma, K. Schreckenberg, and G. Valatin. 2018. Business attitudes towards funding ecosystem services provided by urban forests. Ecosystem Services 32:159-169. https://doi.org/10.1016/j.ecoser.2018.07.006

den Uyl, R. M., and P. P. J. Driessen. 2015. Evaluating governance for sustainable development - insights from experiences in the Dutch fen landscape. Journal of Environmental Management 163:186-203. https://doi.org/10.1016/j.jenvman.2015.08.022

Derissen, S., and U. Latacz-Lohmann. 2013. What are PES? A review of definitions and an extension. Ecosystem Services 6:12-15. https://doi.org/10.1016/j.ecoser.2013.02.002

Diswandi, D. 2017. A hybrid Coasean and Pigouvian approach to payment for ecosystem services program in West Lombok: Does it contribute to poverty alleviation? Ecosystem Services 23:138-145. https://doi.org/10.1016/j.ecoser.2016.12.005

Duncan, E. 2006. Payments for environmental services. An equitable approach for reducing poverty and conserving nature. WWF, Gland, Switzerland.

Engel, S. 2015. The devil in the detail: a practical guide on designing payments for environmental services. International Review of Environmental and Resource Economics 9(1-2):131-177. https://doi.org/10.1561/101.00000076
Engel, S., and A. Muller. 2016. Payments for environmental services to promote "climate smart agriculture"? Potential and challenges. Agricultural Economics 47(S1):173-184. https://doi. org/10.1111/agec.12307

Ezzine-De-Blas, D., C. Dutilly, J. A. Lara-Pulido, G. Le Velly, and A. Guevara-Sanginés. 2016. Payments for environmental services in a policymix: spatial and temporal articulation in Mexico. PLoS ONE 11(4):e0152514. https://doi.org/10.1371/journal.pone.0152514

Fairhead, J., M. Leach, and I. Scoones. 2012. Green grabbing: a new appropriation of nature? Journal of Peasant Studies 39 (2):237-261. https://doi.org/10.1080/03066150.2012.671770

Farley, J. 2020. Green growth: restorative economics for a postcarbon planet. Ecological Citizen 3(Suppl B):23-33.

Farley, J., A. Aquino, A. Daniels, A. Moulaert, D. Lee, and A. Krause. 2010. Global mechanisms for sustaining and enhancing PES schemes. Ecological Economics 69(11):2075-2084. https:// doi.org/10.1016/i.ecolecon.2010.02.016

Farley, J., and R. Costanza. 2010. Payments for ecosystem services: from local to global. Ecological Economics 69 (11):2060-2068. https://doi.org/10.1016/j.ecolecon.2010.06.010

Favretto, N., L. C. Stringer, A. J. Dougill, M. Dallimer, J. S. Perkins, M. S. Reed, J. R. Atlhopheng, and K. Mulale. 2016. Multi-criteria decision analysis to identify dryland ecosystem service trade-offs under different rangeland land uses. Ecosystem Services 17:142-151. https://doi.org/10.1016/j.ecoser.2015.12.005

Ferraro, P. J. 2008. Asymmetric information and contract design for payments for environmental services. Ecological Economics 65 (4):810-821. https://doi.org/10.1016/j.ecolecon.2007.07.029

Fletcher, R. 2010. Neoliberal environmentality: towards a poststructuralist political ecology of the conservation debate. Conservation and Society 8(3):171-181.

Fletcher, R., and B. Büscher. 2017. The PES conceit: revisiting the relationship between payments for environmental services and neoliberal conservation. Ecological Economics 132:224-231. https://doi.org/10.1016/j.ecolecon.2016.11.002

Friis, C., J. Ø. Nielsen, I. Otero, H. Haberl, J. Niewöhner, and P. Hostert. 2016. From teleconnection to telecoupling: taking stock of an emerging framework in land system science. Journal of Land Use Science 11(2):131-153. https://doi.org/10.1080/1747423X.2015.1096423

Gatiso, T. T., B. Vollan, R. Vimal, and H. S. Kühl. 2018. If possible, incentivize individuals not groups: evidence from land-in-thefield experiments on forest conservation in rural Uganda. Conservation Letters 11(1):e12387. https://doi.org/10.1111/ conl.12387

Georgescu-Roegen, N. 1971. The entropy law and the economic process. Havard University Press, Cambridge, Massachusetts, USA. https://doi.org/10.4159/harvard.9780674281653

Gibson, C. C., E. Ostrom, and T. K. Ahn. 2000. The concept of scale and the human dimensions of global change: a survey. Ecological Economics 32(2):217-239. https://doi.org/10.1016/ $\underline{\text { S0921-8009(99)00092-0 }}$ 
Gómez-Baggethun, E., R. de Groot, P. L. Lomas, and C. Montes. 2010. The history of ecosystem services in economic theory and practice: from early notions to markets and payment schemes. Ecological Economics 69(6):1209-1218. https://doi.org/10.1016/j. ecolecon.2009.11.007

Gómez-Baggethun, E., and M. Ruiz-Pérez. 2011. Economic valuation and the commodification of ecosystem services. Progress in Physical Geography 35(5):613-628. https://doi. org/10.1177/0309133311421708

Graeber, D. 2001. Toward an anthropological theory of value: the false coin of our own dreams. Palgrave Macmillan, New York, New York, USA. https://doi.org/10.1057/9780312299064

Grima, N., S. J. Singh, B. Smetschka, and L. Ringhofer. 2016. Payment for ecosystem services (PES) in Latin America: analysing the performance of 40 case studies. Ecosystem Services 17:24-32. https://doi.org/10.1016/j.ecoser.2015.11.010

Hahn, T., C. McDermott, C. Ituarte-Lima, M. Schultz, T. Green, and M. Tuvendal. 2015. Purposes and degrees of commodification: economic instruments for biodiversity and ecosystem services need not rely on markets or monetary valuation. Ecosystem Services 16:74-82. https://doi.org/10.1016/ j.ecoser.2015.10.012

Hayes, T., T. Grillos, L. L. Bremer, F. Murtinho, and E. Shapiro. 2019. Collective PES: more than the sum of individual incentives. Environmental Science and Policy 102:1-8. https://doi. org/10.1016/j.envsci.2019.09.010

Hayes, T., F. Murtinho, and H. Wolff. 2017. The impact of payments for environmental services on communal lands: an analysis of the factors driving household land-use behavior in Ecuador. World Development 93:427-446. https://doi.org/10.1016/ j.worlddev.2017.01.003

Huber, M. T. 2017. Value, nature, and labor: a defense of Marx. Capitalism Nature Socialism 28(1):39-52. https://doi. org/10.1080/10455752.2016.1271817

Huberman, D. 2008. A gateway to PES: using payments for ecosystem services for livelihoods and landscapes. Markets and incentives for livelihoods and landscapes series No. 1. Forest Conservation Programme, International Union for the Conservation of Nature, Gland, Switzerland. [online] URL: https://www.iucn.org/sites/dev/files/import/downloads/ a gateway to pes d huberman.pdf

Huber-Stearns, H. R., D. E. Bennett, S. Posner, R. C. Richards, J. B. H. Fair, S. J. M. Cousins, and C. L. Romulo. 2017. Socialecological enabling conditions for payments for ecosystem services. Ecology and Society 22(1):18. https://doi.org/10.5751/ ES-08979-220118

Huber-Stearns, H. R., J. H. Goldstein, and E. A. Duke. 2013. Intermediary roles and payments for ecosystem services: a typology and program feasibility application in Panama. Ecosystem Services 6:104-116. https://doi.org/10.1016/j.ecoser.2013.09.006

Kallis, G., E. Gómez-Baggethun, and C. Zografos. 2013. To value or not to value? That is not the question. Ecological Economics 94(C):97-105. https://doi.org/10.1016/j.ecolecon.2013.07.002
Karsenty, A. 2011. Payments for environmental services and development. Combining conservation incentives with investment. Perspective 7:1-4. https://doi.org/10.19182/agritrop/00056

Kemkes, R. J., J. Farley, and C. J. Koliba. 2010. Determining when payments are an effective policy approach to ecosystem service provision. Ecological Economics 69(11):2069-2074. https://doi. org/10.1016/j.ecolecon.2009.11.032

Kolinjivadi, V., G. Van Hecken, D. V. Almeida, J. Dupras, and N. Kosoy. 2017. Neoliberal performatives and the 'making' of payments for ecosystem services (PES). Progress in Human Geography 43(1):3-25. https://doi.org/10.1177/0309132517735707

Kosoy, N., and E. Corbera. 2010. Payments for ecosystem services as commodity fetishism. Ecological Economics 69(6):1228-1236. https://doi.org/10.1016/j.ecolecon.2009.11.002

Kosoy, N., M. Martínez Tuna, R. Muradian, and J. MartínezAlier. 2007. Payments for environmental services in watersheds: insights from a comparative study of three cases in Central America. Ecological Economics 61(2-3):446-455. https://doi. org/10.1016/j.ecolecon.2006.03.016

Kull, C. A., X. Arnauld de Sartre, and M. Castro-Larrañaga. 2015. The political ecology of ecosystem services. Geoforum 61:122-134. https://doi.org/10.1016/j.geoforum.2015.03.004

Lambin, E. F., and P. Meyfroidt. 2011. Global land use change, economic globalization, and the looming land scarcity. Proceedings of the National Academy of Sciences 108 (9):3465-3472. https://doi.org/10.1073/pnas.1100480108

Lima, L. S., T. Krüger, and J. García-Marquez. 2017. Uncertainties in demonstrating environmental benefits of payments for ecosystem services. Ecosystem Services 27:139-149. https://doi.org/10.1016/j.ecoser.2017.09.005

Lockie, S. 2013. Market instruments, ecosystem services, and property rights: assumptions and conditions for sustained social and ecological benefits. Land Use Policy 31:90-98. https://doi. org/10.1016/j.landusepol.2011.08.010

Loft, L. 2011. Market mechanisms for financing the reduction of emissions from deforestation and degradation in developing countries (REDD) - learning from payments for ecosystem services schemes. International Journal of Biodiversity Science, Ecosystem Services and Management 7(3):204-216. https://doi. org/10.1080/21513732.2011.645072

Martínez-Alier, J. 2002. The environmentalism of the poor: a study of ecological conflicts and valuation. Edward Elgar Publishing, Cheltenham, UK.

Martínez-Alier, J. 2014. The environmentalism of the poor. Geoforum 54:239-241. https://doi.org/10.1016/j.geoforum.2013.04.019

Martin-Ortega, J., and K. A. Waylen. 2018. PES what a mess? An analysis of the position of environmental professionals in the conceptual debate on payments for ecosystem services. Ecological Economics 154:218-237. https://doi.org/10.1016/j.ecolecon.2018.08.001

Matheus, F. S. 2018. The role of forests and protected areas in climate change mitigation: a review and critique of the ecosystem services and REDD+ approaches. Desenvolvimento e Meio Ambiente 46:23-36. https://doi.org/10.5380/dma.v46i0.54187 
Matulis, B. S. 2017. Persistent neoliberalisation in PES: taxes, tariffs, and the World Bank in Costa Rica. Conservation and Society 15(2):147-156.

Matzdorf, B., C. Sattler, and S. Engel. 2013. Institutional frameworks and governance structures of PES schemes. Forest Policy and Economics 37:57-64. https://doi.org/10.1016/j. forpol.2013.10.002

McAfee, K. 2012. The contradictory logic of global ecosystem services markets. Development and Change 43(1):105-131. https:// doi.org/10.1111/j.1467-7660.2011.01745.X

McAfee, K. 2016. Green economy and carbon markets for conservation and development: a critical view. International Environmental Agreements: Politics, Law and Economics 16 (3):333-353. https://doi.org/10.1007/s10784-015-9295-4

McAfee, K., and E. N. Shapiro. 2010. Payments for ecosystem services in Mexico: nature, neoliberalism, social movements, and the state. Annals of the Association of American Geographers 100 (3):579-599. https://doi.org/10.1080/00045601003794833

McCarthy, J. 2005. Devolution in the woods: community forestry as hybrid neoliberalism. Environment and Planning A: Economy and Space 37(6):995-1014. https://doi.org/10.1068/a36266

McElwee, P. D. 2012. Payments for environmental services as neoliberal market-based forest conservation in Vietnam: panacea or problem? Geoforum 43(3):412-426. https://doi.org/10.1016/j. geoforum.2011.04.010

McElwee, P., T. Nghiem, H. Le, H. Vu, and N. Tran. 2014. Payments for environmental services and contested neoliberalisation in developing countries: a case study from Vietnam. Journal of Rural Studies 36:423-440. https://doi.org/10.1016/j.jrurstud.2014.08.003

Meadowcroft, J. 2002. Politics and scale: some implications for environmental governance. Landscape and Urban Planning 61:169-179. https://doi.org/10.1016/S0169-2046(02)00111-1

Meyfroidt, P., E. F. Lambin, K. H. Erb, and T. W. Hertel. 2013. Globalization of land use: distant drivers of land change and geographic displacement of land use. Current Opinion in Environmental Sustainability 5(5):438-444. https://doi.org/10.1016/ j.cosust.2013.04.003

Milder, J. C., S. J. Scherr, and C. Bracer. 2010. Trends and future potential of payment for ecosystem services to alleviate rural poverty in developing countries. Ecology and Society 15(2):4. https://doi.org/10.5751/ES-03098-150204

Millennium Ecosystem Assessment. 2005. Ecosystems and human well-being: synthesis. Island, Washington, D.C., USA.

Moher, D., A. Liberati, J. Tetzlaff, and D. G. Altman. 2009. Preferred reporting items for systematic reviews and metaanalyses: the PRISMA statement. PLoS Medicine 6(7):e1000097. https://doi.org/10.1371/journal.pmed.1000097

Mongeon, P., and A. Paul-Hus. 2016. The journal coverage of Web of Science and Scopus: a comparative analysis. Scientometrics 106(1):213-228. https://doi.org/10.1007/s11192-015-1765-5

Muniz, R., and M. J. Cruz. 2015. Making nature valuable, not profitable: Are payments for ecosystem services suitable for degrowth? Sustainability 7(8):10895-10921. https://doi.org/10.3390/ su70810895

Muradian, R. 2013. Payments for ecosystem services as incentives for collective action. Society \& Natural Resources 26 (10):1155-1169. https://doi.org/10.1080/08941920.2013.820816

Muradian, R., M. Arsel, L. Pellegrini, F. Adaman, B. Aguilar, B. Agarwal, E. Corbera, D. Ezzine de Blas, J. Farley, G. Froger, E. Garcia-Frapolli, E. Gómez-Baggethun, J. Gowdy, N. Kosoy, J. F. Le Coq, P. Leroy, P. May, P. Méral, P. Mibielli, R. Norgaard, B. Ozkaynak, U. Pascual, W. Pengue, M. Perez, D. Pesche, R. Pirard, J. Ramos-Martin, L. Rival, F. Saenz, G. Van Hecken, A. Vatn, B. Vira, and K. Urama. 2013. Payments for ecosystem services and the fatal attraction of win-win solutions. Conservation Letters 6 (4):274-279. https://doi.org/10.1111/j.1755-263X.2012.00309.X

Muradian, R., E. Corbera, U. Pascual, N. Kosoy, and P. H. May. 2010. Reconciling theory and practice: an alternative conceptual framework for understanding payments for environmental services. Ecological Economics 69(6):1202-1208. https://doi. org/10.1016/j.ecolecon.2009.11.006

Narloch, U., A. G. Drucker, and U. Pascual. 2017. What role for cooperation in conservation tenders? Paying farmer groups in the High Andes. Land Use Policy 63:659-671. https://doi.org/10.1016/ j.landusepol.2015.09.017

Nieratka, L. R., D. B. Bray, and P. Mozumder. 2015. Can payments for environmental services strengthen social capital, encourage distributional equity, and reduce poverty? Conservation and Society 13(4):345-355.

Norgaard, R. B. 2010. Ecosystem services: from eye-opening metaphor to complexity blinder. Ecological Economics 69 (6):1219-1227. https://doi.org/10.1016/j.ecolecon.2009.11.009

Organisation for Economic Co-operation and Development (OECD). 2013. Scaling-up finance mechanisms for biodiversity. OECD Publishing, Paris, France.

Ostrom, E. 1990. Governing the commons. The evolution of institutions for collective action. Cambridge University Press, Cambridge, UK.

Oxfam. 2014. Building a new agricultural future, supporting agroecology for the people and the planet. Oxfam Issue Briefing, Oxford, UK.

Pagiola, S., A. Arcenas, and G. Platais. 2005. Can payments for environmental services help reduce poverty? An exploration of the issues and the evidence to date from Latin America. World Development 33(2):237-253. https://doi.org/10.1016/j.worlddev.2004.07.011

Parrique, T., J. Barth, F. Briens, C. Kerschner, A. Kraus-Polk, A. Kuokkanen, and J. H. Spangenberg. 2019. Decoupling debunked: evidence and arguments against green growth as a sole strategy for sustainability. European Environmental Bureau, Brussels, Belgium.

Pattanayak, S. K., S. Wunder, and P. J. Ferraro. 2010. Show me the money: Do payments supply environmental services in developing countries? Review of Environmental Economics and Policy 4(2):254-274. https://doi.org/10.1093/reep/req006

Paudyal, K., H. Baral, and R. J. Keenan. 2016. Local actions for the common good: Can the application of the ecosystem services 
concept generate improved societal outcomes from natural resource management? Land Use Policy 56:327-332. https://doi. org/10.1016/j.landusepol.2015.11.010

Perman, R., Y. Ma, M. Common, D. Maddison, and J. McGilvray. 2011. Natural resource and environmental economics. Fourth edition. Pearson Education Limited, Harlow, UK.

Petheram, L., and B. M. Campbell. 2010. Listening to locals on payments for environmental services. Journal of Environmental Management 91(5):1139-1149. https://doi.org/10.1016/j. jenvman.2010.01.002

Petschow, U., S. Lange, D. Hofmann, E. Pissarskoi, N. aus dem Moore, T. Korfhage, A. Schoofs, and H. Ott. 2018. Gesellschaftliches Wohlergehen innerhalb planetarer Grenzen. Der Ansatz einer vorsorgeorientierten Postwachstumsposition. Umweltbundesamt, Dessau-Roßlau, Germany.

Polanyi, K. 1957. The great transformation. The political and economic origins of our time. Beacon Press, Boston, Massachusetts, USA. https://doi.org/10.1002/9780470755679. $\underline{\mathrm{ch} 4}$

Porras, I., B. Aylward, and J. Dengel. 2013. Monitoring payments for watershed services schemes in developing countries. International Institute for Environment and Development, London, UK. [online] URL: https://pubs.iied.org/pdfs/16525IIED. pdf

Porras, I., M. Grieg-Gran, and N. Neves. 2008. All that glitters: a review of payments for watershed services in developing countries. International Institute for Environment and Development, London, UK.

Reed, M. S., K. Allen, A. Attlee, A. J. Dougill, K. L. Evans, J. O. Kenter, J. Hoy, D. McNab, S. M. Stead, C. Twyman, A. S. Scott, M. A. Smyth, L. C. Stringer, and M. J. Whittingham. 2017. A place-based approach to payments for ecosystem services. Global Environmental Change 43:92-106. https://doi.org/10.1016/j. gloenvcha.2016.12.009

Reed, M. S., A. Moxey, K. Prager, N. Hanley, J. Skates, A. Bonn, C. D. Evans, K. Glenk, and K. Thomson. 2014. Improving the link between payments and the provision of ecosystem services in agri-environment schemes. Ecosystem Services 9:44-53. https:// doi.org/10.1016/j.ecoser.2014.06.008

Reutemann, T., S. Engel, and E. Pareja. 2016. How (not) to pay - field experimental evidence on the design of REDD+ payments. Ecological Economics 129:220-229. https://doi.org/10.1016/j. ecolecon.2016.05.020

Robertson, M. M. 2006. The nature that capital can see: science, state, and market in the commodification of ecosystem services. Environment and Planning D: Society and Space 24:367-387. https://doi.org/10.1068/d3304

Rode, J., E. Gómez-Baggethun, and T. Krause. 2015. Motivation crowding by economic incentives in conservation policy: a review of the empirical evidence. Ecological Economics 117:270-282. https://doi.org/10.1016/j.ecolecon.2014.11.019

Roth, R. J., and W. Dressler. 2012. Market-oriented conservation governance: the particularities of place. Geoforum 43(3):363-366. https://doi.org/10.1016/j.geoforum.2012.01.006
Salzman, J., G. Bennett, N. Carroll, A. Goldstein, and M. Jenkins. 2018. The global status and trends of payments for ecosystem services. Nature Sustainability 1(3):136-144. https://doi. org/10.1038/s41893-018-0033-0

Sattler, C., and B. Matzdorf. 2013. PES in a nutshell: from definitions and origins to PES in practice - approaches, design process and innovative aspects. Ecosystem Services 6:2-11. https:// doi.org/10.1016/j.ecoser.2013.09.009

Sattler, C., S. Trampnau, S. Schomers, C. Meyer, and B. Matzdorf. 2013. Multi-classification of payments for ecosystem services: How do classification characteristics relate to overall PES success? Ecosystem Services 6:31-45. https://doi.org/10.1016/j.ecoser.2013.09.007

Scales, I. R. 2015. Paying for nature: What every conservationist should know about political economy. Oryx 49(2):226-231. https://doi.org/10.1017/S0030605314000015

Schlager, E., and E. Ostrom. 1992. Property-rights regimes and natural resources: a conceptual analysis. Land Economics 68 (3):249-262. https://doi.org/10.2307/3146375

Schleyer, C., C. Görg, J. Hauck, and K. J. Winkler. 2015. Opportunities and challenges for mainstreaming the ecosystem services concept in the multi-level policy-making within the EU. Ecosystem Services 16:174-181. https://doi.org/10.1016/j.ecoser.2015.10.014

Schomers, S., and B. Matzdorf. 2013. Payments for ecosystem services: a review and comparison of developing and industrialized countries. Ecosystem Services 6:16-30. https://doi. org/10.1016/j.ecoser.2013.01.002

Schröter, B., B. Matzdorf, E. Hackenberg, and J. Hauck. 2018. More than just linking the nodes: civil society actors as intermediaries in the design and implementation of payments for ecosystem services - the case of a blue carbon project in Costa Rica. Local Environment 23(6):635-651. https://doi. org/10.1080/13549839.2018.1460808

Shelley, B. G. 2011. What should we call instruments commonly known as payments for environmental services? A review of the literature and a proposal. Annals of the New York Academy of Sciences 1291(1):209-225. https://doi.org/10.1111/j.1749-6632.2010.05941. $\underline{x}$

Smith, S., P. Rowcroft, M. Everard, L. Couldrick, M. Reed, H. Rogers, T. Quick, C. Eves, and C. White. 2013. Payments for ecosystem services: a best practice guide. Department for Environment Food \& Rural Affairs, London, UK. [online] URL: https://www.cbd.int/financial/pes/unitedkingdom-bestpractice.pdf

Sommerville, M. M., J. P. G. Jones, and E. J. Milner-Gulland. 2009. A revised conceptual framework for payments for environmental services. Ecology and Society 14(2):34. https://doi. org/10.5751/ES-03064-140234

Sorice, M. G., C. J. Donlan, K. J. Boyle, W. Xu, and S. Gelcich. 2018. Scaling participation in payments for ecosystem services programs. PLoS ONE 13(3):e0192211. https://doi.org/10.1371/ journal.pone.0192211

Souza, C. A., A. L. Casteli Figueiredo Gallardo, E. Donaire da Silva, Y. Cunha de Mello, C. A. Righe, and M. L. Solera. 2016. 
Environmental services associated with the reclamation of areas degraded by mining: potential for payments for environmental services. Ambiente \& Sociedade 19(2):137-168. https://doi. org/10.1590/1809-4422asoc129835v1922016

Swyngedouw, E. 2000. Authoritarian governance, power, and the politics of rescaling. Environment and Planning D: Society and Space 18(1):63-76. https://doi.org/10.1068/d9s

Tacconi, L. 2012. Redefining payments for environmental services. Ecological Economics 73(1):29-36. https://doi.org/10.1016/ j.ecolecon.2011.09.028

Thompson, B. S. 2018. Institutional challenges for corporate participation in payments for ecosystem services (PES): insights from Southeast Asia. Sustainability Science 13(4):919-935. https://doi.org/10.1007/s11625-018-0569-y

Van der Horst, D. 2011. Adoption of payments for ecosystem services: an application of the Hägerstrand model. Applied Geography 31:668-676. https://doi.org/10.1016/j.apgeog.2010.12.001

Van Hecken, G., J. Bastiaensen, and F. Huybrechs. 2015. What's in a name? Epistemic perspectives and payments for ecosystem services policies in Nicaragua. Geoforum 63:55-66. https://doi. org/10.1016/j.geoforum.2015.05.020

Van Hecken, G., J. Bastiaensen, and W. F. Vásquez. 2012. The viability of local payments for watershed services: empirical evidence from Matiguás, Nicaragua. Ecological Economics 74:169-176. https://doi.org/10.1016/j.ecolecon.2011.12.016

Van Hecken, G., V. Kolinjivadi, C. Windey, P. McElwee, E. Shapiro-Garza, F. Huybrechs, and J. Bastiaensen. 2018. Silencing agency in payments for ecosystem services (PES) by essentializing a neoliberal 'monster' into being: a response to Fletcher \& Büscher's 'PES Conceit.' Ecological Economics 144:314-318. https://doi.org/10.1016/j.ecolecon.2017.10.023

Van Noordwijk, M., and B. Leimona. 2010. Principles for fairness and efficiency in enhancing environmental services in Asia: payments, compensation, or co-investment? Ecology and Society 15(4):17. https://doi.org/10.5751/ES-03664-150417

Vatn, A. 2010. An institutional analysis of payments for environmental services. Ecological Economics 69(6):1245-1252. https://doi.org/10.1016/j.ecolecon.2009.11.018

Wunder, S. 2005. Payments for environmental services: some nuts and bolts. CIFOR Occasional Paper 42:1-25.

Wunder, S. 2013. When payments for environmental services will work for conservation. Conservation Letters 6(4):230-237. https:// doi.org/10.1111/conl.12034

Wunder, S. 2015. Revisiting the concept of payments for environmental services. Ecological Economics 117:234-243. https://doi.org/10.1016/j.ecolecon.2014.08.016

Wynne-Jones, S. 2014. "Reading for difference" with payments for ecosystem services in Wales. Critical Policy Studies 8 (2):148-164. https://doi.org/10.1080/19460171.2013.857474 


\section{APPENDIX 1}

Table A1. Identified PES definitions.

\begin{tabular}{|c|c|c|}
\hline $\begin{array}{l}\text { Author and } \\
\text { year }\end{array}$ & Definition & $\begin{array}{l}\text { Publication } \\
\text { identified in } \\
\text { the literature } \\
\text { review (L) or } \\
\text { via snowball } \\
\text { system (S) }\end{array}$ \\
\hline
\end{tabular}

Wunder

(2005:3)

Corbera et al. "MES and PES consist of transferring economic resources (2007:366)

Ferraro

(2008:810)

Sommerville et al. (2009:2)

Milder et al. (2010:1)

“(1) [...] voluntary transaction[s] where (2) a well-defined service (or a land-use likely to secure that service) (3) is being 'bought' by a (minimum one) ES buyer (4) from a (minimum one) ES provider (5) if and only if the ES provider secures ES provision (conditionality)"

from providers to consumers of ecosystem services so that the former benefit economically while the latter receive the right to use the resources provided by the service in question. The difference between MES and PES resides in their underlying institutional framework. [...] PES are not actual markets where ecosystem services are sold to service buyers. The commodity is ill-defined, and, in most cases, governments play an intermediary role by mobilizing resources from consumers to a government fund, which then distributes financial resources to ecosystem-service stewards at a pre-established price"

PES "generally have two common features. First, they are voluntary. Second, participation involves a contract between the conservation agent and the landowner. The landowner agrees to manage an ecosystem according to agreed-upon rules and receives a payment (in-kind or cash) conditional on compliance with the contract"

"approaches that aim to (1) transfer positive incentives to environmental service providers that are (2) conditional on the provision of the services, where successful implementation is based on a consideration of (1) additionality and (2) varying institutional contexts"

"Payment for ecosystem services (PES) is a market-based $\mathrm{S}$ approach to environmental management that compensates land stewards for ecosystem conservation and restoration. [...] We define PES to include direct payments from ecosystem service beneficiaries to land stewards, as well 
as indirect payments earned through eco-certified production (Food and Agriculture Organization 2007)"

Muradian et "a transfer of resources between social actors, which aims

al.

(2010:1205)

Karsenty

(2011:1)

Porras et al. (2013:7)

Tacconi

$(2012: 35)$

Smith et al. (2013:13) to create incentives to align individual and/or collective land use decisions with the social interest in the management of natural resources. Such transfers (monetary or non-monetary) are embedded in social relations, values and perceptions, which are decisive in conditioning PES design and outcomes"

"a payment to an agent for services provided to other agents (wherever they may be in space and time) by means of a deliberate action aimed at preserving, restoring or increasing an environmental service agreed by the parties. PES therefore result from a voluntary agreement between parties, in other words they are based on contracts that are explicit or implicit (oral agreements), and which set out the service expected and the corresponding payments, as well as for how long the service must be provided"

"A transaction in which a supplier or seller of the ecosystem service is responding to the offer of compensation from a single or multiple beneficiaries (NGO, private party, local or central government entity) and/ or a beneficiary separate from the seller which is not a central government entity, compensation is conditional upon the land management practices specified by the program, and the voluntary component is only attached to the supply-side of the transaction in that the provider 'voluntarily' enters in to the contract."

"PES scheme is a transparent system for the additional provision of environmental services through conditional payments to voluntary providers. [...] PES schemes are essentially instruments to maintain or recreate the supply of ES through the provision of incentives"

"[...] PES is used to describe schemes in which the beneficiaries, or users, of ecosystem services provide payment to the stewards, or providers, of ecosystem services. In practice, PES often involves a series of payments to land or other natural resource managers in return for a guaranteed flow of ecosystem services (or, more commonly, for management actions likely to enhance their provision) over-and-above what would otherwise be provided in the absence of payment. 
Payments are made by the beneficiaries of the services in question, for example, individuals, communities, businesses or government acting on behalf of various parties"

Engel

"a positive economic incentive where environmental service (ES) providers can voluntarily apply for a payment that is conditional either on ES provision or on an activity clearly linked to ES provision"

Wunder " (1) voluntary transactions (2) between service users (3) and service providers (4) that are conditional on agreed rules of natural resource management (5) for generating offsite services"

Davies et al. "'a transfer of resources between ES buyers and sellers (2018:160) that aims to improve provision of ES for the benefit of society and the environment' The following principles apply:

- Voluntariness - stakeholders ideally enter into a PES agreement on a voluntary basis, however governments may act on their behalf, or regulate involvement, if necessary.

- Payment source - payments are made by the beneficiaries of ES (citizens, businesses, or governments acting on their behalf). This includes those benefitting from reputational enhancement or actions that compensate for (unregulated) environmental harm.

- Conditionality - payment is conditional on the delivery of quantified ES, or on the implementation of robust land use practices proven to deliver ES benefits.

- Additionality - ES benefits (or proxy land use practices) are over- and-above the baseline (or business-as-usual) level, and do not lead to the loss or degradation of ES elsewhere" 


\section{APPENDIX 2}

Table A2. Coding system for the systematic literature review addressing the influence of spatial scales on PES program effectiveness; cited literature is assigned to the main categories of the coding system and divided into publications directly identified in the literature review and further publications identified based on a snowball system.

\begin{tabular}{|c|c|c|}
\hline Category & Identified publications & $\begin{array}{l}\text { Publication identified in } \\
\text { the literature review (L) or } \\
\text { via snowball system }(\mathrm{S})\end{array}$ \\
\hline $\begin{array}{l}\text { Scale of ES } \\
\text { provision versus } \\
\text { scale of ES } \\
\text { benefits }\end{array}$ & $\begin{array}{l}\text { Corbera et al. } 2009 \\
\text { Farley et al. } 2010 \\
\text { Kemkes et al. } 2010 \\
\text { Banerjee et al. } 2013 \\
\text { Huber-Stearns et al. } 2013 \\
\text { Den Uyl and Driessen } 2015 \\
\text { Kull et al. } 2015\end{array}$ & $\begin{array}{l}\mathrm{L} \\
\mathrm{L} \\
\mathrm{L} \\
\mathrm{L} \\
\mathrm{L} \\
\mathrm{L} \\
\mathrm{L}\end{array}$ \\
\hline $\begin{array}{l}\text { Cross-scale } \\
\text { mismatches } \\
\text { between } \\
\text { ecological and } \\
\text { social and } \\
\text { institutional } \\
\text { systems }\end{array}$ & $\begin{array}{l}\text { Maedowcroft } 2002 \\
\text { Corbera et al. } 2009 \\
\text { Loft } 2011 \\
\text { Van der Horst } 2011 \\
\text { Reed et al. } 2014 \\
\text { den Uyl and Driessen } 2015 \\
\text { Favretto et al. } 2016 \\
\text { Cerra } 2017 \\
\text { Huber-Stearns et al. } 2017 \\
\text { Reed et al. } 2017\end{array}$ & $\begin{array}{l}\text { S } \\
\text { L } \\
\text { L } \\
\text { L } \\
\text { L } \\
\text { L } \\
\text { S } \\
\text { L } \\
\text { S } \\
\text { L }\end{array}$ \\
\hline $\begin{array}{l}\text { Advantages of } \\
\text { local and } \\
\text { regional PES } \\
\text { programs }\end{array}$ & $\begin{array}{l}\text { Farley et al. } 2010 \\
\text { Kemkes et al. } 2010 \\
\text { Banerjee et al. } 2013 \\
\text { Lockie } 2013 \\
\text { OECD } 2013 \\
\text { Agrawal et al. } 2014 \\
\text { den Uyl and Driessen } 2015 \\
\text { Grima et al. } 2016 \\
\text { Paudyal et al. } 2016 \\
\text { Sorice et al. } 2018 \\
\text { Thompson } 2018\end{array}$ & $\begin{array}{l}\text { L } \\
\text { L } \\
\text { L } \\
\text { L } \\
\text { S } \\
\text { L } \\
\text { L } \\
\text { L } \\
\text { S } \\
\text { L } \\
\text { L }\end{array}$ \\
\hline $\begin{array}{l}\text { Advantages of } \\
\text { international } \\
\text { PES programs } \\
\text { (IPES) }\end{array}$ & $\begin{array}{l}\text { Corbera et al. } 2009 \\
\text { Corbera } 2012 \\
\text { Huber-Stearns et al. } 2013 \\
\text { McElwee et al. } 2014 \\
\text { Den Uyl and Driessen } 2015 \\
\text { Kull et al. } 2015\end{array}$ & $\begin{array}{l}\text { L } \\
\text { L } \\
\text { L } \\
\text { S } \\
\text { L } \\
\text { L }\end{array}$ \\
\hline
\end{tabular}


Schleyer et al. 2015

Cook et al. 2016

Ezzine-De-Blas et al. 2016

L

Cerra 2017

Schröter et al. 2018

$\mathrm{L}$

$\mathrm{L}$

Leakage and Pattanayak et al. 2010 


\section{APPENDIX 3}

Table A3. Coding system for the systematic literature review addressing critique of the PES approach; cited literature is assigned to the main categories of the coding system and divided into publications directly identified in the literature review and further publications identified based on a snowball system.

\begin{tabular}{|c|c|c|c|}
\hline Category & Subcategory & Identified publications & $\begin{array}{l}\text { Publication } \\
\text { identified in } \\
\text { the literature } \\
\text { review (L) or } \\
\text { via snowball } \\
\text { system (S) }\end{array}$ \\
\hline \multirow[t]{3}{*}{$\begin{array}{l}\text { Critique of the } \\
\text { neoliberal patterns } \\
\text { of the payments for } \\
\text { ecosystem service } \\
\text { approach }\end{array}$} & $\begin{array}{l}\text { General critique } \\
\text { on neoliberal } \\
\text { conservation } \\
\text { approaches }\end{array}$ & $\begin{array}{l}\text { Fletcher } 2010 \\
\text { Büscher et al. } 2012 \\
\text { Fletcher and Büscher } 2017 \\
\text { Allen } 2018\end{array}$ & $\begin{array}{l}\text { S } \\
\text { S } \\
\text { L } \\
\text { L }\end{array}$ \\
\hline & $\begin{array}{l}\text { Understandings } \\
\text { of the term } \\
\text { "neoliberalism", }\end{array}$ & $\begin{array}{l}\text { Büscher et al. } 2012 \\
\text { Matulis } 2013 \\
\text { Apostolopoulou et al. } 2014 \\
\text { McElwee et al. } 2014 \\
\text { Hahn et al. } 2015 \\
\text { Matulis } 2017 \\
\text { Van Hecken et al. } 2018\end{array}$ & $\begin{array}{l}\text { S } \\
\text { L } \\
\text { L } \\
\text { L } \\
\text { L } \\
\text { L } \\
\text { S }\end{array}$ \\
\hline & $\begin{array}{l}\text { Are PES market- } \\
\text { based? }\end{array}$ & $\begin{array}{l}\text { Cerney et al. } 2005 \\
\text { Higgins et al. } 2014 \\
\text { Wynne-Jones } 2014 \\
\text { Fletcher and Büscher } 2017 \\
\text { Kolinjivadi et al. } 2017 \\
\text { Matulis } 2017\end{array}$ & $\begin{array}{l}\text { S } \\
\text { L } \\
\text { L } \\
\text { L } \\
\text { S } \\
\text { L }\end{array}$ \\
\hline $\begin{array}{l}\text { Critique of the } \\
\text { monetary valuation } \\
\text { and } \\
\text { commodification of } \\
\text { ecosystem services }\end{array}$ & $\begin{array}{l}\text { Critique of the } \\
\text { focus on } \\
\text { monetary } \\
\text { exchange values }\end{array}$ & $\begin{array}{l}\text { Graeber } 2001 \\
\text { Corbera } 2012 \\
\text { McAfee } 2012 \\
\text { Kallis et al. } 2013 \\
\text { Hahn et al. } 2015 \\
\text { Kull et al. } 2015 \\
\text { Muniz and Cruz } 2015 \\
\text { Rode et al. } 2015 \\
\text { Scales 2015 } \\
\text { Allen 2018 } \\
\text { Van Hecken et al. } 2018 \\
\text { Biely et al. } 2018\end{array}$ & $\begin{array}{l}\text { S } \\
\text { L } \\
\text { L } \\
\text { L } \\
\text { L } \\
\text { L } \\
\text { L } \\
\text { S } \\
\text { L } \\
\text { L } \\
\text { S } \\
\text { S }\end{array}$ \\
\hline
\end{tabular}




\begin{tabular}{|c|c|c|c|}
\hline & $\begin{array}{l}\text { Critique of the } \\
\text { commodification } \\
\text { of nature }\end{array}$ & $\begin{array}{l}\text { Bakker } 2003 \\
\text { Kosoy and Corbera } 2010 \\
\text { Norgaard } 2010 \\
\text { McElwee } 2012 \\
\text { Kallis et al. } 2013 \\
\text { Scales } 2015\end{array}$ & $\begin{array}{l}\mathrm{S} \\
\mathrm{S} \\
\mathrm{S} \\
\mathrm{L} \\
\mathrm{L} \\
\mathrm{L}\end{array}$ \\
\hline & $\begin{array}{l}\text { Critique of the } \\
\text { applied } \\
\text { valuation } \\
\text { methods }\end{array}$ & $\begin{array}{l}\text { Muradian et al. } 2010 \\
\text { McAfee } 2016 \\
\text { Lima et al. } 2017\end{array}$ & $\begin{array}{l}\mathrm{S} \\
\mathrm{S} \\
\mathrm{S}\end{array}$ \\
\hline $\begin{array}{l}\text { Critique regarding } \\
\text { social and } \\
\text { institutional aspects }\end{array}$ & $\begin{array}{l}\text { Underlying } \\
\text { power structures } \\
\text { and power } \\
\text { imbalances } \\
\text { affect PES } \\
\text { programs } \\
\text { negatively }\end{array}$ & $\begin{array}{l}\text { Kosoy and Corbera } 2010 \\
\text { Muradian et al. } 2010 \\
\text { Muradian et al. } 2013 \\
\text { Muniz and Cruz } 2015 \\
\text { Blanchard et al. } 2016 \\
\text { Fletcher and Büscher } 2017 \\
\text { Swyngedouw } 2000 \\
\text { Petheram and Campbell } 2010 \\
\text { Corbera } 2012 \\
\text { McElwee 2012 } \\
\text { Roth and Dressler } 2012 \\
\text { Kallis et al. 2013 } \\
\text { Apostolopoulou et al. } 2014 \\
\text { Cavanagh and Benjaminsen } 2014 \\
\text { Muniz and Cruz } 2015 \\
\text { Bétrisey et al. } 2016 \\
\text { Matheus } 2018\end{array}$ & $\begin{array}{l}\text { S } \\
\text { S } \\
\text { S } \\
\text { L } \\
\text { L } \\
\text { L } \\
\text { S } \\
\text { S } \\
\text { L } \\
\text { L } \\
\text { L } \\
\text { L } \\
\text { L } \\
\text { S } \\
\text { L } \\
\text { L } \\
\text { L }\end{array}$ \\
\hline & $\begin{array}{l}\text { Compensation } \\
\text { logic of PES } \\
\text { might foster } \\
\text { existing North- } \\
\text { South } \\
\text { inequalities }\end{array}$ & $\begin{array}{l}\text { Martínez-Alier } 2002 \\
\text { Fairhead et al. } 2012 \\
\text { Martínez-Alier } 2014 \\
\text { Muniz and Cruz } 2015 \\
\text { Van Hecken et al. } 2015 \\
\text { Matheus } 2018\end{array}$ & $\begin{array}{l}\mathrm{S} \\
\mathrm{S} \\
\mathrm{S} \\
\mathrm{L} \\
\mathrm{L} \\
\mathrm{L}\end{array}$ \\
\hline
\end{tabular}

